\title{
Intra- and interspecific shell variability of the genus Urocythereis Ruggieri, 1950 (Ostracoda: Hemicytheridae) in the La Strea Bay (Ionian Sea, Italy)
}

\author{
Giuseppe AIELLO ${ }^{1,}$, , Diana BARRA ${ }^{2}$, Roberta PARISI ${ }^{3}$ \\ 1,2,3 Dipartimento di Scienze della Terra, dell'Ambiente e delle Risorse, Università degli \\ Studi di Napoli Federico II, Largo San Marcellino 10, 80138 Napoli, Italy. \\ *Corresponding author: aie64llo@hotmail.com \\ ${ }^{2}$ Email: dibarra@unina.it \\ ${ }^{3}$ Email: robyparisi@alice.it \\ ${ }^{1}$ urn:lsid:zoobank.org:author:DBCEA76E-42E4-4899-ABFC-9884160E6FB1 \\ 2 urn:lsid:zoobank.org:author:6D83D636-3FAF-4247-BF51-ABF7AAD01434 \\ ${ }^{3}$ urn:Isid:zoobank.org:author:15FA09D2-9ED6-4314-87EA-8750D4F75BF4
}

\begin{abstract}
The variability of the reticulum pattern, ornamentation and outline of the Urocythereis populations of the La Strea Bay is analysed. The results show that the shell features of the form $U$. distinguenda (Neviani, 1928) (=U. oblonga Brady, 1866) have to be included within the high variability range of U. margaritifera (G.W. Müller, 1894). Consequently, it is suggested that in the upper infralittoral waters of the inlet two (and not three, as stated in previous investigations) species of the genus Urocythereis presently live. A second form, displaying a relatively low variability, is described as a new species, $U$. ilariae sp. nov.
\end{abstract}

Keywords. Intraspecific variability, shell morphology, Urocythereis, celation, outline analysis.

Aiello G., Barra D. \& Parisi R. 2016. Intra- and interspecific shell variability of the genus Urocythereis Ruggieri, 1950 (Ostracoda: Hemicytheridae) in the La Strea Bay (Ionian Sea, Italy). European Journal of Taxonomy 193: 1-35. http://dx.doi.org/10.5852/ejt.2016.193

\section{Introduction}

During a study of the Recent ostracods of the La Strea Bay more than two thousand valves of Urocythereis were collected and assigned to three species (Aiello et al. 2006). Most specimens were assigned to U. margaritifera (G.W. Müller, 1894) and $U$. distinguenda (Neviani, 1928), while a third form was left in open nomenclature and named Urocythereis sp. 1.

The presence of shells exhibiting transitional characters between the former two species (then included in U. margaritifera) indicated an unsolved taxonomic issue. For a correct evaluation of the degree of intraspecific variability in Urocythereis, we have re-examined sub-recent specimens recovered in this relatively small (length: $2,5 \mathrm{~km}$, maximum width: $1 \mathrm{~km}$ ) inlet, also known as Porto Cesareo Lagoon. It 
is in its northern part connected with the Ionian Sea, and is characterised by a subtropical biocoenosis (Parenzan 1976, 1983, 1984). The environmental setting is entirely included in the upper part of the infralittoral zone, with water depth not exceeding five meters. Ecological parameters vary over seasons and sectors of the bay (Fig. 1).

It can be supposed that environmental factors influence, at least in part, the development of different shell morphs. Consequently, the studied specimens may represent slightly different ecomorphotypes belonging to dead assemblages.

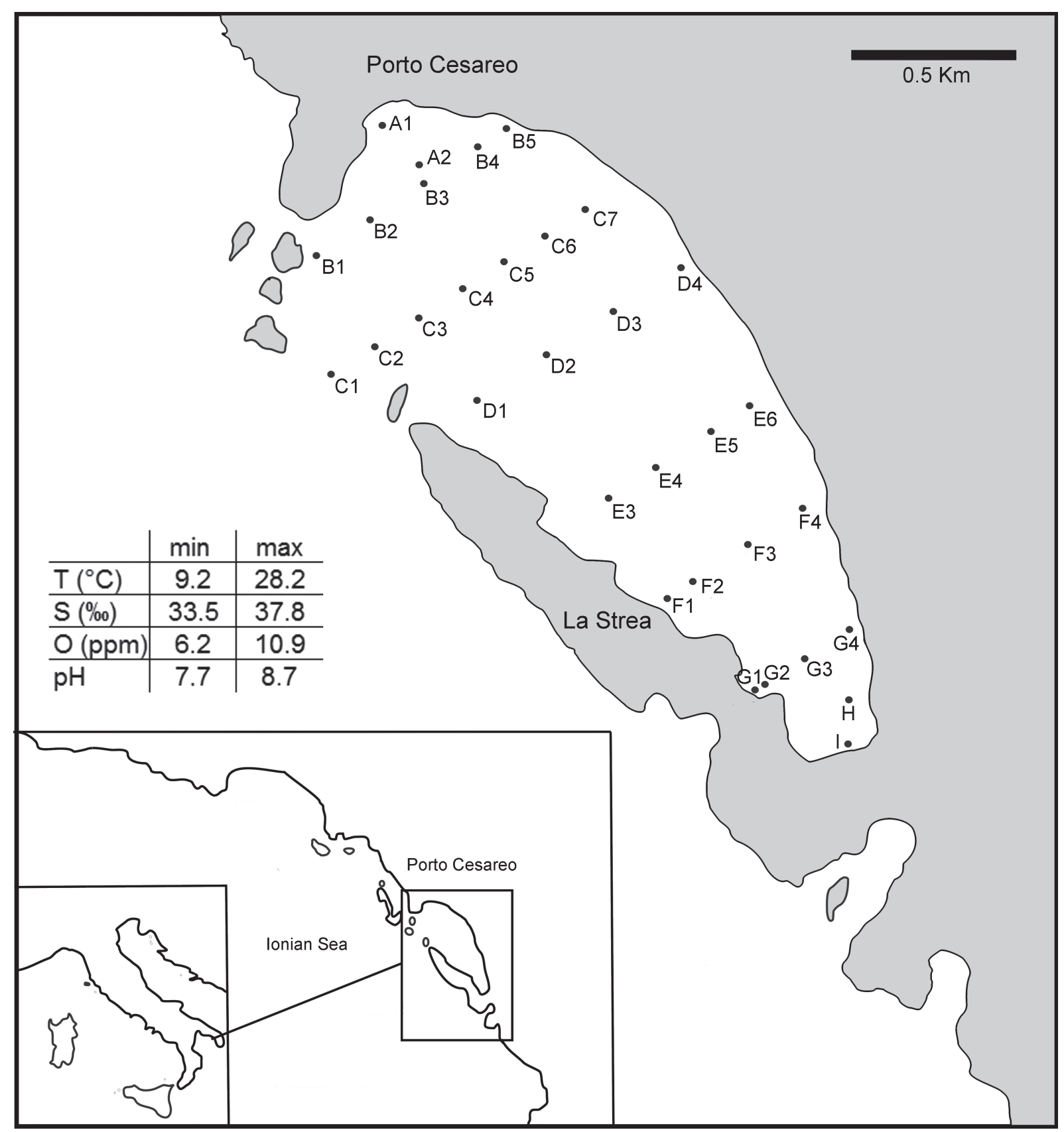

Fig. 1. Location map of the study area and sampling stations and range of selected physico-chemical parameters of the La Strea Bay (data from Belmonte \& Rubino 1988; Mercurio et al. 2000; Gherardi et al. 2001). 
With the aim to minimize the unavoidable taxonomist's subjectivity, we have employed two morphological methods of discrimination: the first is the comparison of ornament morphology, taking into account the features of the reticulation especially; the other is the morphometric analysis of the outline by means of the computer program Morphomatica (Linhart et al. 2006).

To be more precise, our intent is: 1) to define intrademic, non-polytypic (sensu Sylvester-Bradley 1976) variations of shell features, namely the morphological variability of the Urocythereis demes - panmictitc populations (freely interbreeding, sharing the same gene pool, relatively confined) of the La Strea Bay; 2) to assess how many Urocythereis species are present in the Recent/sub-Recent thanatocoenoses of the bay; we consider this attempt as a step toward a better understanding of the complex morphology of the genus from a paleontological viewpoint; 3) to characterize groups of fossae, stable within species and variable among species (e.g., Al-Furaih 1977).

\section{Intraspecific variability in ostracod shells}

The studies on intraspecific morphological variations include investigations on soft parts (i.a., Rossetti \& Martens 1996; Martens et al. 1998; Yin et al. 1999), internal features of smooth valves (i.a., Aiello et al. 2007, and references therein), surface ornamentation (i.a., Keen 1982; Peypouquet et al. 1988; Neil 2000) and outline (Baltanas \& Danielopol 2011, and references therein). Intraspecific variability can be continuous or discontinuous, and continuous variations may seem very simple to analyse if compared with polymorphism sensu Ford (1940), that is "the occurrence together in the same locality of two or more discontinuous forms of a species in such proportions that the rarest of them cannot be maintained merely by recurrent mutation" (see Clark 1976 for discussion and extensive references). Yet, when we deal with morphologically highly variable taxa, also non-polymorphic species highlight complex taxonomic problems.

Here, we focus on the continuous variation of shape and ornament in Urocythereis, with special regard to reticulation. Urocythereis species may show all five types of continuous variation of fine sculpture (in position, form, strength of expression, size and number of elements) described by Liebau (1971).

High-degree variability in ostracod shell sculpture, derived from both genetic and environmental factors, is a recurrent problem experienced by authors dealing with studies on shallow marine assemblages (e.g., Hartmann 1982), which always include some phenotypically plastic species. Phenotypic plasticity, that is the ability of an organism to express different phenotypes under different environmental conditions (see, e.g., West-Eberhard 1989), may represent a fundamental resource for effective adaptation to coastal environments, characterized by wide ranges and rapid changes of ecological parameters, and is a major drawback for systematic investigations. Seemingly distinct features occurring in some infra-littoral ostracod taxa lead taxonomists to propose a large number of specific names, which frequently have not stood the test of time. In other cases, taxonomists "lumped" together very different forms (see, e.g., a brief discussion on the genus Carinocythereis in Aiello \& Szczechura 2001).

\section{The genus Urocythereis}

The genus Urocythereis was originally described by Ruggieri in 1950, with the intent to accommodate three strictly related hemicytherid species, with subrectangular valves and an amphidont hinge provided with a reniform posterior tooth in the right valve. These species were Cytherina favosa Roemer, 1838, designated as type species, Cythereis margaritifera G.W. Müller, 1894 and Cythereis distinguenda Neviani, 1928, from the Pliocene to Recent of the Mediterranean area. Since then, dozens of species have been included in Urocythereis, especially from the Neogene to Recent of the Mediterranean area and the eastern Atlantic. Aiello et al. (2004) assigned the south-western Atlantic species, previously included in Urocythereis, to the new genus Ruggiericythere, due to the different structure of the reticulation-ridges system. The allied genus Yezocythere Hanai \& Ikeya, 1991 includes eastern Asian 
species with a low subcentral tubercle, lacking in Urocythereis. Even though the authors recognized a second distinctive feature, the smaller size of the median frontal scar, the value of this character at genus level remained questionable. The Neogene to Recent Eastern African and Asian records of Urocythereis (e.g., U. pohangensis Huh \& Whatley, 1997; U. salebrosa Ahmad, Neale \& Siddiqui, 1991), as well as its presence in Paleogene deposits (e.g., U. bertelsae Kielbowicz, 1988), are, in our opinion, questionable.

In our present state of knowledge, Urocythereis is a Cenozoic genus possibly restricted to the infralittoral and uppermost circalittoral zone (0-40 m, Athersuch 1977) of the Eastern Atlantic - Mediterranean area. The taxonomy of this genus is complex due to the unusually wide variability of the shell ornamentation and, consequently, species limits within the genus remain partly undefined.

A major contribution to the knowledge of the genus is the study by Athersuch (1977), who provided a revision of all the then known living and some fossil species, in addition to an excellent iconography. He described detailed ornamental patterns of five allied species (U. distinguenda (Neviani, 1928), U. margaritifera, U. favosa (Roemer, 1838), plus U. neapolitana and U. britannica Athersuch, 1977, described as new species) based on "nine arbitrary groups" of fossae. The author used these patterns to demonstrate differences among groups of species, one being later described by Ruggieri \& Russo (1980) as a new genus, Nonurocythereis. These groups are not effective for discrimination at species level. The outline of the muri, as well as the shape and dimension of the fossae, and their degree of anastomosis, are rarely steady, so that reticulation varies "even between members of the same species" (Athersuch 1977). Uncertainty is increased due to the frequent occurrence of celation (Sylvester-Bradley \& Benson 1971), a morphological noise able to conceal, in some cases almost completely, ornamental patterns. In a similar way, the relationship between normal pores and reticulation, used by authors for ostracod morphology studies (e.g., Hunt \& Yasuhara 2010), is blurred by various degrees of development of shell calcification. Normal pores are well distinct in internal view, not in external view, and consequently the relationship between pores and reticulum pattern is difficult to establish.

\section{Reticulation}

Shell reticulation represents a complex of features that, since the early contributions of Pokorny (1969a, 1969b), Liebau $(1969,1971)$ and Benson $(1971,1972)$, has been considered by ostracod workers a fascinating object of study for taxonomy, evolution and related research fields. Ornament pattern definition has been carried out especially on hemicytherid and trachyleberid taxa, frequently showing a well-defined and more or less stable reticulation. Interspecific variations, in related species, are sometimes limited to a few fossae and highly consistent in each species (Okada 1982b). The analysis of the fossal pattern has been used for species discrimination (e.g., Al-Furaih 1977) and in studies on the evolution and ontogeny of Trachybeleridoidea (i.a., Hunt 2007a, 2007b; Hunt \& Yasuhara 2010; Tanaka et al. 2011). Jones (1988) showed the possibility to extend the reticulation analysis to Paleozoic taxa.

Okada (1981, 1982a, 1982b) extensively studied the relationship of the epidermal cells to the reticulation pattern and he recognized a direct correspondence between fossae and the underlying epidermal cells. Since the muri represent the boundary of adjacent cells, the mesh arrangement reflects cell lineages, commonly considered as genetically determined (i.a., Liebau 1971; Benson 1972; Irizuki 1993; Hunt 2007a).

Reticulated species frequently show a pattern of ridges where homologous fossae can be recognized by their constancy in shape, number and arrangement and by the presence of landmarks such as pores, ridges or spines (i.a. Benson 1972; Liebau 1991; Hunt 2007b; Hunt \& Yasuhara 2010). In Urocythereis, the number of fossae is relatively stable within species, while their shape and arrangement vary widely, pores are frequently obscured by calcification and the features of anatomical landmarks, for example muscle scars, can be difficult to define. Furthermore, alae, carinae or tubercles are not present in Urocythereis. Consequently, an unambiguous identification of fossae and an accurate quantitative study 
of their variations (e.g., Hunt \& Yasuhara 2010 on Poseidonamicus) has proved unattainable. Ruiz et al. (2006) hypothesized a direct influence of environmental factors on the variability of Urocythereis reticulation.

\section{Celation as a taxonomic issue}

The development of an outer layer of calcite, the tegmen, overlapping the ornament of the valves, has been named "celation" by Sylvester-Bradley \& Benson (1971). The authors considered the tegmen as a secondary thickening paving over the outer surface and thus obscuring, to some degrees, primary reticulation. Benson (1972) hypothesized that the development of the tegmen represents the architectural response to the requirement of a high shell strength. In deep and cold waters, this lightweight solution may represent a case of parsimony in design balancing the scarcity of available skeletal material with the development of high resistance to compression. Athersuch (1977) observed that the development of celation (not recorded in juveniles) in Urocythereis distinguenda is related neither to depth nor to other known ecological parameters, and suggested that the growth of the tegmen depends from the age of the individuals: an intense celation would be typical of older adults. Another hypothesis considers celation as a response to calcium saturated bottom waters, pertaining to the "environmentally cued polymorphism" described by Peypouquet et al. (1980, 1981, 1988). Anyway, because celation varies continuously, we agree with Neil (2000) on preferring the term "environmentally-cued variation". In this particular case the terms "celation" and "agradation" ("aggradation" in Neil 2000) are equivalent.

These two hypotheses are not mutually exclusive.

The ecological demands of an infralittoral genus can hardly be compared with the bathyal and abyssal taxa studied by Benson (1972), who supposed that the secondary development of the top of the muri in shallow water species, such as Cythere lutea O.F. Müller, 1785 and Hemicythere villosa (Sars, 1866), has to be an adaptation to high energy sedimentary regimens. The attested preference of Urocythereis for sandy bottoms (e.g., Athersuch et al. 1989; Aiello et al. 2006) and relatively agitated waters supports this interpretation. It is understood that celation may be a consequence of simple genetic variation, or a mixture of genetic and environmental effects. In any case, the occurrence of specimens with more or less celated shells poses a taxonomic problem, whether we are dealing with two species (in this case $U$. margaritifera and $U$. distinguenda), with individuals of the same species that have possibly built their valves in different physico-chemical conditions, or, alternatively, with younger and older adults of the same species.

\section{How many Urocythereis species occur in the La Strea Bay?}

The assignment of the Urocythereis specimens of the La Strea Bay to the above mentioned three species by Aiello \& Barra (in Aiello et al. 2006) followed the original description and figures of G.W. Müller (1894) and subsequent literature for U. margaritifera, and Athersuch (1977) for U. distinguenda. Cythereis margaritifera was described by G.W. Müller in his monograph on the ostracods living in the Gulf of Naples, and later recorded from Pliocene to Recent in the Mediterranean area. Cythereis distinguenda is the name proposed by Neviani (1928) to replace the pre-occupied Cythere oblonga Brady, 1866 (non C. oblonga M'Coy, 1844). Athersuch (1977) discussed nomenclatural problems and designated a neotype for $U$. distinguenda from the shallow waters of Cyprus. This author figured U. margaritifera specimens from Müller's collection, showing individuals with rounded fossae as well as with fossae reduced to punctae and foveolae (sensu Athersuch et al. 1989) because of celation. In the same paper the specimens assigned to $U$. distinguenda show a marked celation with small-sized irregular punctae-foveolae.

A third form present in the La Strea Bay bottom samples was left in open nomenclature and named $U$. sp. 1 because of the resemblance with the specimens from the beach sands of Tripoli figured by 
Table 1. Coordinates, depth and granulometry of the studied samples. Abbreviations: VSF $=$ Very Fine Sands, FS = Fine Sands, MS = Medium Sands, CS = Coarse Sands.

\begin{tabular}{|c|c|c|c|c|}
\hline Samples & Longitude E & Latitude N & Depth (m) & Grain size \\
\hline A1 & $17^{\circ} 53.67^{\prime}$ & $40^{\circ} 15.92^{\prime}$ & 0.43 & FS \\
\hline $\mathrm{A} 2$ & $17^{\circ} 53.76^{\prime}$ & $40^{\circ} 15.83^{\prime}$ & 1.30 & MS-FS \\
\hline B1 & $17^{\circ} 53.57^{\prime}$ & $40^{\circ} 15.64^{\prime}$ & 3.21 & CS-FS \\
\hline B2 & $17^{\circ} 53.64^{\prime}$ & $40^{\circ} 15.71^{\prime}$ & 2.43 & CS-MS \\
\hline B3 & $17^{\circ} 53.73^{\prime}$ & $40^{\circ} 15.78^{\prime}$ & 2.40 & $\mathrm{CS}$ \\
\hline B4 & $17^{\circ} 53.87^{\prime}$ & $40^{\circ} 15.88^{\prime}$ & 1.40 & CS \\
\hline B5 & $17^{\circ} 53.93^{\prime}$ & $40^{\circ} 15.91^{\prime}$ & 0.90 & CS-MS \\
\hline $\mathrm{C} 1$ & $17^{\circ} 53.52^{\prime}$ & $40^{\circ} 15.34^{\prime}$ & 4.40 & $\mathrm{CS}$ \\
\hline $\mathrm{C} 2$ & $17^{\circ} 53.61^{\prime}$ & $40^{\circ} 15.40^{\prime}$ & 4.78 & $\mathrm{CS}$ \\
\hline $\mathrm{C} 3$ & $17^{\circ} 53.72^{\prime}$ & $40^{\circ} 15.46^{\prime}$ & 4.50 & CS-FS \\
\hline $\mathrm{C} 4$ & $17^{\circ} 53.83^{\prime}$ & $40^{\circ} 15.53^{\prime}$ & 3.40 & $\mathrm{CS}$ \\
\hline $\mathrm{C} 5$ & $17^{\circ} 53.92^{\prime}$ & $40^{\circ} 15.61^{\prime}$ & 2.58 & CS-FS \\
\hline C6 & $17^{\circ} 54.02^{\prime}$ & $40^{\circ} 15.66^{\prime}$ & 1.73 & $\mathrm{CS}$ \\
\hline $\mathrm{C} 7$ & $17^{\circ} 54.10^{\prime}$ & $40^{\circ} 15.72^{\prime}$ & - & $\mathrm{CS}$ \\
\hline D1 & $17^{\circ} 53.85^{\prime}$ & $40^{\circ} 15.33^{\prime}$ & 1.52 & MS-FS \\
\hline D2 & $17^{\circ} 54.01^{\prime}$ & $40^{\circ} 15.38^{\prime}$ & 2.30 & CS-MS \\
\hline D3 & $17^{\circ} 54.17^{\prime}$ & $40^{\circ} 15.49^{\prime}$ & 1.51 & CS-FS \\
\hline D4 & $17^{\circ} 54.32^{\prime}$ & $40^{\circ} 15.59^{\prime}$ & 1.11 & CS-FS \\
\hline E3 & $17^{\circ} 54.01^{\prime}$ & $40^{\circ} 15.07^{\prime}$ & 1.42 & MS-FS \\
\hline $\mathrm{E} 4$ & $17^{\circ} 54.25^{\prime}$ & $40^{\circ} 15.16^{\prime}$ & 1.50 & CS-MS \\
\hline E5 & $17^{\circ} 54.26^{\prime}$ & $40^{\circ} 15.23^{\prime}$ & 1.49 & FS \\
\hline E6 & $17^{\circ} 54.45^{\prime}$ & $40^{\circ} 15.28^{\prime}$ & 1.30 & MS-FS \\
\hline $\mathrm{F} 1$ & $17^{\circ} 54.28^{\prime}$ & $40^{\circ} 14.84^{\prime}$ & 0.50 & CS-FS \\
\hline $\mathrm{F} 2$ & $17^{\circ} 54.34^{\prime}$ & $40^{\circ} 14.88^{\prime}$ & 0.94 & MS-FS \\
\hline F3 & $17^{\circ} 54.45^{\prime}$ & $40^{\circ} 14.97^{\prime}$ & 1.12 & FS \\
\hline F4 & $17^{\circ} 54.60^{\prime}$ & $40^{\circ} 15.04^{\prime}$ & 1.50 & MS-FS \\
\hline G1 & $17^{\circ} 54.47^{\prime}$ & $40^{\circ} 15.63^{\prime}$ & 0.20 & MS-VFS \\
\hline $\mathrm{G} 2$ & $17^{\circ} 54.52^{\prime}$ & $40^{\circ} 14.67^{\prime}$ & 0.70 & MS \\
\hline G3 & $17^{\circ} 54.57^{\prime}$ & $40^{\circ} 14.71^{\prime}$ & 0.80 & MS-VFS \\
\hline G4 & $17^{\circ} 54.66^{\prime}$ & $40^{\circ} 14.77^{\prime}$ & 0.65 & MS-VFS \\
\hline $\mathrm{H}$ & $17^{\circ} 54.69^{\prime}$ & $40^{\circ} 14.61^{\prime}$ & 0.26 & VFS \\
\hline I & $17^{\circ} 54.69^{\prime}$ & $40^{\circ} 14.51^{\prime}$ & 0.12 & FS \\
\hline
\end{tabular}

Barra (1997). This previously undescribed species has a marked affinity with U. exedata Uliczny, 1969 , especially in the very distinct ocular riblet, a feature homologous to the prominent "ocular ridge" described by Benson (1972) on some Bradleya species. The new species shows a distinct ornamental pattern and specific features. Conversely, it seems very difficult to define an unambiguous boundary between $U$. distinguenda and U. margaritifera, necessitating the examination of "intermediate" morphs, in order to verify the existence of two separate species rather than a single highly variable species.

\section{Material and methods}

All the 32 samples were taken within the depth range of 0.12-4.78 $\mathrm{m}$ bsl (Aiello et al. 2006), from the Recent bottom sediments of the La Strea Bay (Table 1). The samples contained 2133 valves and 128 carapaces, including both adults and young instars. All the specimens were studied and 150 shells were 
selected for analyses and iconography. This study deals exclusively with adult specimens. Young instars were considered only to evaluate the possible occurrence of celation in juveniles.

The analysis of the reticulation pattern and celation variations is based on scanning electron microscopy (SEM) micrographs (carried out at Cisag, Università di Napoli Federico II). The above mentioned high variability of the reticulation in Urocythereis species lead us to select some areas of the shell, where the fossae-muri pattern was detectable with a minimum degree of uncertainty.

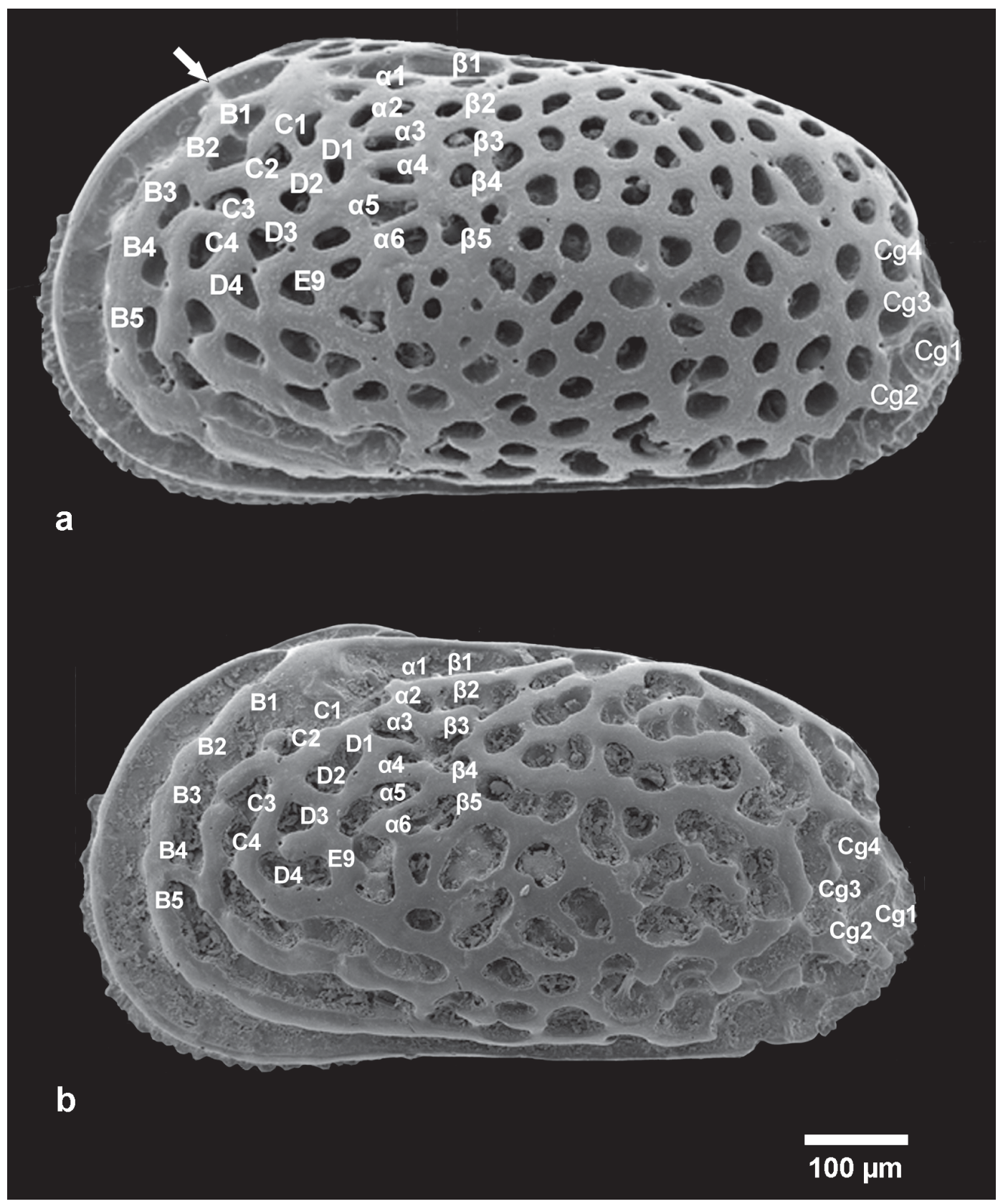

Fig. 2. Scheme of the five fossal groups used for reticulation pattern analysis. White arrow indicates the pre-ocular bridge. A. Urocytheris margaritifera (G.W. Müller, 1894), ABMC 2014/057. B. Urocytheris ilariae sp. nov., ABMC 2014/047. 
Table 2. Catalogue number and sampling stations of the specimens used in the Morphomatica analysis.

\begin{tabular}{cc|cc}
\hline Catalogue number & Samples & Catalogue numbers & Samples \\
\hline ABMC 2014/125 & C4 & ABMC 2014/142 & C5 \\
ABMC 2014/126 & C4 & ABMC 2014/143 & C5 \\
ABMC 2014/127 & D3 & ABMC 2014/144 & D3 \\
ABMC 2014/128 & D3 & ABMC 2014/145 & D3 \\
ABMC 2014/129 & E6 & ABMC 2014/146 & D3 \\
ABMC 2014/130 & E6 & ABMC 2014/147 & D3 \\
ABMC 2014/131 & E6 & ABMC 2014/148 & E6 \\
ABMC 2014/132 & E6 & ABMC 2014/149 & E6 \\
ABMC 2014/133 & E6 & ABMC 2014/150 & E6 \\
ABMC 2014/134 & H & ABMC 2014/151 & G2 \\
ABMC 2014/135 & H & ABMC 2014/152 & G2 \\
ABMC 2014/136 & A2 & ABMC 2014/153 & G2 \\
ABMC 2014/137 & A2 & ABMC 2014/154 & H \\
ABMC 2014/138 & A2 & ABMC 2014/155 & H \\
ABMC 2014/139 & B3 & ABMC 2014/156 & H \\
ABMC 2014/140 & C4 & & \\
\hline
\end{tabular}

The Morphomatica test was performed on drawings in transmitted light. They were carried out by means of a Visopan Reichert, with a magnification of 201 times. The pictures were drawn with a technical pen (thickness of the line: $0.30 \mathrm{~mm}$ ) on tracing paper. The studied specimens are housed in the Aiello Barra Micropaleontological Collection (ABMC), Distar, Università degli Studi di Napoli Federico II.

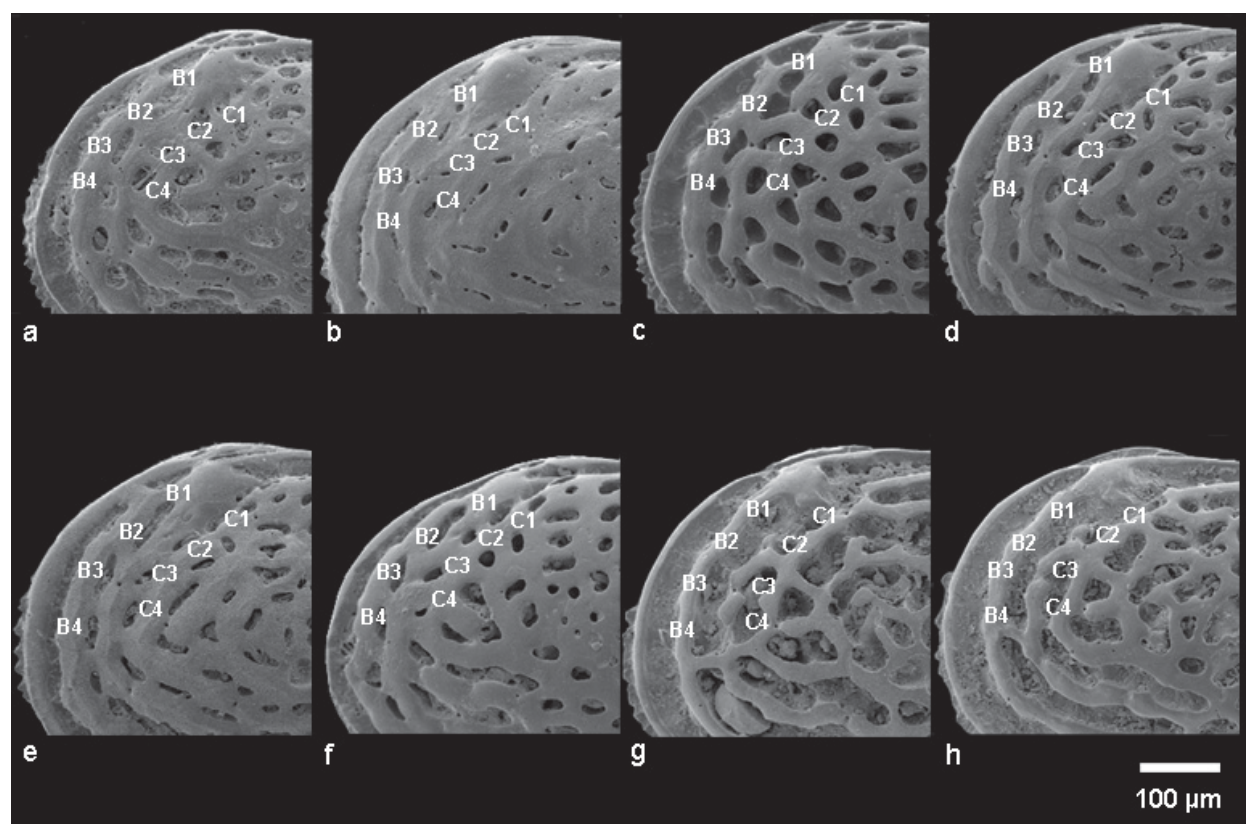

Fig. 3. Detail of the antero-dorsal area in different morphs. - A-F. U. margaritifera (G.W. Müller, 1894). A. ABMC 2014/045. B. ABMC 2014/053. C. ABMC 2014/057. D. ABMC 2014/059. E. ABMC 2014/075. F. ABMC 2014/083. - G-H. U. ilariae sp. nov. G. ABMC 2014/038. H. ABMC 2014/047. 
AIELLO G. et al., Shell variability of Urocythereis in the La Strea Bay (Italy)

\section{Reticulation pattern}

In a highly variable genus such as Urocythereis the purpose of naming the position of all the meshes seems difficult to achieve (in Urocythereis especially in the ventral area and in the posterior half of the shell). Consequently, we identified five arbitrary fossal groups where the pattern can be recognized, both in different species and specimens of the same species, as homologous without uncertainties (Fig. 2).

These groups were selected with the aim to define the structure of inter- and intra-specific reticulation pattern variations. We chose muri/fossae sets that could be reliably considered homologous in $U$. margaritifera and $U$. exedata. The two species are quite different and we hope that these groups may be used for future comparisons among other species of Urocythereis.

Fossal groups are defined as follows:

a) Pre-ocular fossa (Pre-ocular bridge): presence of a preocular connection between the anterior marginal rim and the ocular riblet, as figured in Fig. 2.

b) Anterodorsal group: a group of fossae located in the subocular area (B1, B2, B3, B4, C1, C2, C3, C4) as numbered in Figs 2 and 3.

c) D3-D4-E9 group: these fossae form a triangular area situated in the anterocentral area, behind the fourth concentric anterior ridge as figured in Figs 2 and 4.

d) Dorsal median group: Athersuch (1977) defined this group as "two vertical rows of fossae directly beneath the post-ocular sinus and directed towards the sub-central area" $(\alpha 1-\alpha 6, \beta 1-\beta 5$ in Figs 2 and 5);

e) Caudal group: the group of fossae $(\mathrm{Cg} 1-\mathrm{Cg} 4)$ located on the caudal process area as figured in Figs 2 and 6.

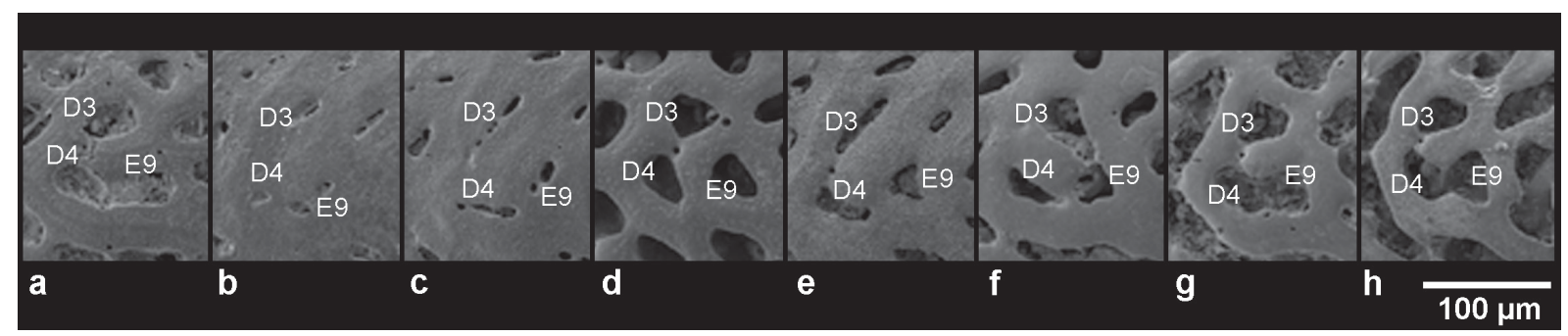

Fig. 4. Detail of the antero-central area showing the fossal group D3-D4-E9 in different morphs. A-F. U. margaritifera (G.W. Müller, 1894). A. ABMC 2014/045. B. ABMC 2014/50. C. ABMC 2014/053. D. ABMC 2014/057. E. ABMC 2014/075. F. ABMC 2014/083. - G-H. U. ilariae sp. nov. G. ABMC 2014/047. H. ABMC 2014/069.

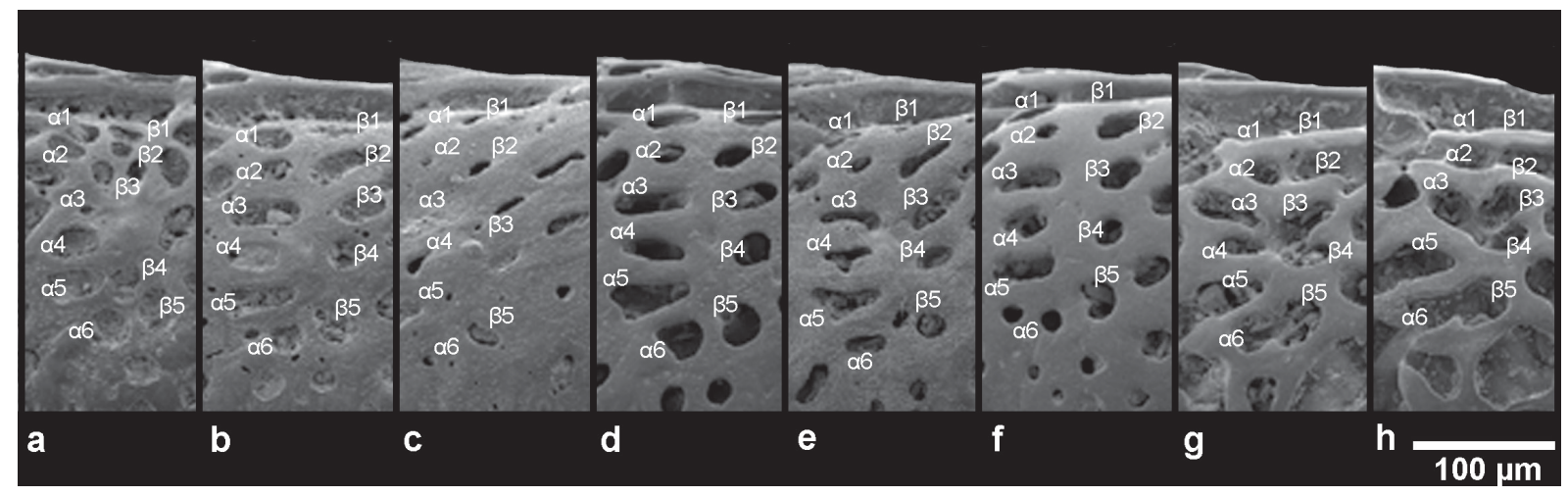

Fig. 5. Dorsal median group in different morphs. - A-F. U. margaritifera (G.W. Müller, 1894). A. ABMC 2014/037. B. ABMC 2014/04. C. ABMC 2014/053. D. ABMC 2014/057. E. ABMC 2014/075. F. ABMC 2014/083. - G-H. U. ilariae sp. nov. G. ABMC 2014/047. H. ABMC 2014/069. 


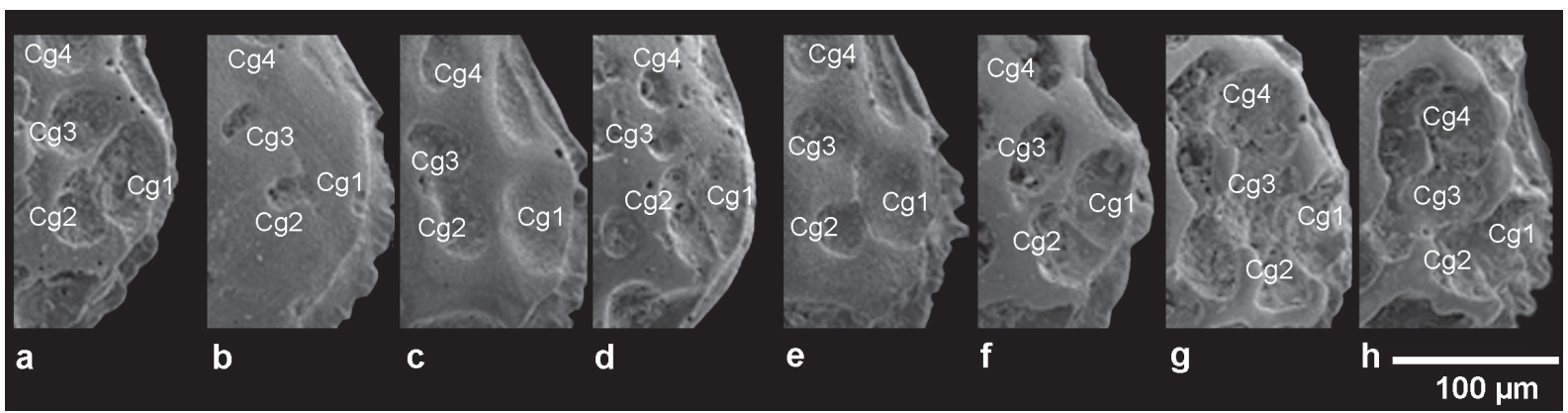

Fig. 6. Detail of the caudal group in different morphs. - A-F. U. margaritifera (G.W. Müller, 1894). A. ABMC 2014/045. B. ABMC 2014/053. C. ABMC 2014/059. D. ABMC 2014/062. E. ABMC 2014/075. F. ABMC 2014/083. - G-H. U. ilariae sp. nov. G. ABMC 2014/038. H. ABMC 2014/069.

\section{Outline analysis}

A quantitative analysis of ostracod morphology has been carried out by means of different methods, including techniques of outline analysis (for a partial review, see Baltanás \& Danielopol 2011). In recent years, ostracod researchers seem leaning towards using the computer program Morphomatica, based on a B-spline algorithm specifically adapted to ostracod valve outline (Baltanás et al. 2003; Linhart et al. 2006), which provides valuable results in specific discrimination (i.a., Iepure et al. 2007; Danielopol et al. 2008; Ligios \& Gliozzi 2012; Mazzini et al. 2014). The method has been described, for example, in Gross et al. 2008. This technique has been used mostly on smooth or weakly ornamented ostracod taxa, whereas we tested its effectiveness by using it to discriminate strongly reticulated forms. The material consists of 20 left valves of the Urocythereis margaritifera-distinguenda group and 11 left valves of $U$. ilariae sp. nov. (Table 2). On the basis of the shell features a clear discrimination between female and male valves is not possible. The selection of the valves showing a higher $\mathrm{h} / \mathrm{l}$ ratio would be, in absence of discontinuity, a mere example of circular reasoning. Consequently, we selected the best-preserved valves, with no regard for their supposed sex, well-aware of the resulting limitations. Due to the presence of unevenly preserved marginal denticulation we chose, unlike the usual procedure using transmitted light microscope photographs, to analyse and digitize drawings generated using Visopan Reichert at a magnification of $\times 201$. The results of Morphomatica were processed using Cluster analysis, nonmetric multidimensional scaling (n-MDS) and analysis of similarities (One-way ANosim Pairwise Test) by means of the program PRIMER 6 (Clarke \& Gorley 2006).

\section{Results}

\section{Celation, variability and specific assignment of Urocythereis sp. 1}

The morphological variations in Urocythereis sp. 1 appear limited when compared with the $U$. margaritifera-distinguenda group. Celation is rare and the fossae are never hidden by secondary calcification; the structure of reticulation is somewhat constant. The basic pattern shows a close resemblance to the Pliocene form described by Uliczny (1969) as Urocythereis favosa exedata and elevated to the rank of species by Mostafawi \& Matzke-Karasz (2006). Some stable shell features of $U$. sp. 1 are different from those of the Pliocene taxon, leading us to describe a new species, named $U$. ilariae sp. nov. as discussed in the systematic section.

\section{Fossae shape and size variations and celation in the $\boldsymbol{U}$. margaritifera-distinguenda group}

Brady (1866) described a species from Recent sponge-sands of the Eastern Mediterranean as Cythere oblonga, characterized by "somewhat distant, oblong, pittings". The name C. oblonga was, however, preoccupied by C. oblonga M'Coy, 1844; therefore, in 1928 Neviani assigned a new name, Cythereis distinguenda, recognized by Athersuch $(1977,1982)$ as the "next available name for Brady's species". 
In previous investigations, the present authors used the size of the fossae to discriminate between $U$. margaritifera and $U$. distinguenda, being relatively large in the former species and very small in the latter one. The finding of specimens exhibiting transitional features makes their specific attribution difficult. The following morphs can be defined on the basis of the size and shape of the fossae:

Morph a (commonly assigned to U. margaritifera): medium-sized fossae, equidimensional, except in the anterodorsal zone where they are medium- to small-sized; generally rounded, elongated or fused in the anteroventral area (e.g., Fig. 16A, H);

Morph $\mathrm{b}$ (commonly assigned to $U$. margaritifera): medium-sized fossae rounded and equidimensional on the whole surface of the shell (e.g., Figs 2A; 16B);

Morph c ("transitional" form): mesh size from medium to very small, generally rounded (e.g., Fig. 17E);

Morph d ("transitional" form): fossae mainly elongated, from small to medium-sized (e.g., Fig. 17B);

Morph e ("transitional" form): the anterior area shows fossae very small or completely celated; the remaining fossae are small and rounded (e.g., Fig. 17D);

Morph $\mathrm{f}$ (commonly assigned to $U$. distinguenda): small-sized fossae; narrow and elongated in the anterior part of the valve, rounded in the posterior part and mixed in the central area (e.g., Fig. 16D);

Morph g (commonly assigned to $U$. distinguenda): small-sized fossae, rounded or elongated in the posterior half of the shell; very small (reduced into puncta) to completely celated in the anterior half (Fig. 17C);

Morph h (commonly assigned to $U$. distinguenda): size of fossae ranging from small to very small; elongated or rounded (Fig. 16G).

It has to be noted that in this latter group the muri are generally densely or sparsely papillate; in specimens showing intense celation, papillae occur on the tegmen and are very sparse or lacking in correspondence with the underlying muri, revealing the reticulation pattern (Fig. 7). A similar feature was observed by Benson (1972) in the species Poseidonamicus nudus Benson, 1972.

In our opinion, these data suggest that $U$. margaritifera and $U$. distinguenda are morphotypes of the same species.

\section{Reticulation variability}

The fossal groups show the following variations:

\section{a. Pre-ocular fossa (pre-ocular bridge)}

In $U$. margaritifera/distinguenda, a murus located in the antero-dorsal corner, in pre-ocular position, generally connects the anterior marginal rim and the ocular riblet, which delimitate the marginal furrow (Figs 3A, C-E; 19D), forming a pre-ocular fossa. The pre-ocular bridge is more or less well defined in $U$. margaritifera/distinguenda, including celated specimens, where it is highly developed and the preocular fossa is reduced (Fig. 3B). In some specimens of U. margaritifera/distinguenda, the bridge is absent and the furrow is continuous up to the eye tubercle (Fig. 3F).

The pre-ocular fossa never occurs in U. ilariae sp. nov. (Fig. 3G-H).

\section{b. Anterodorsal group. Fossal pattern B1-B4 - C1-C4}

In $U$. ilariae sp. nov., the presence of a murus between the fossae B5 and B4, connecting the second and the third marginal riblets, is a stable feature and a possible landmark when comparing species 
of Urocythereis. It is subdued in some very rare celated specimens (Fig. 18G). A composite fossa, including the anastomized fossae B1, B2, B3, B4, C1 and C2, shows slight intraspecific variability (Figs 2B; 3G-H); in some specimens (Fig. 18C, F) B4 and C4 are connected.

In $U$. margaritifera/distinguenda, $\mathrm{B}$ and $\mathrm{C}$ fossae never connect. The fossae $\mathrm{B} 1$ and $\mathrm{B} 2$ may be divided (Fig. 17G), partially fused (Figs 2; 16B) or merged (Fig. 3E-F). Fossae B2-B3-B4 are never joined, $\mathrm{C} 1$ and $\mathrm{C} 2$ are usually divided (Fig. 3C, F) and can show some degrees of anastomosis (Fig. 3D-E). In some specimens celation may simulate mesh subdivision. For example, in Fig. 3B the $\mathrm{C} 2$ mesh is almost completely closed by tegmen and small foveolae mirror the underlying fossa. Fossae $\mathrm{C} 3$ and $\mathrm{C} 4$ are never fused.

\section{c. D3-D4-E9 group}

In U. margaritifera/distinguenda, D4 and E9 are usually distinct (Fig. 4B-F), rarely joined together (Fig. 4A). In a few specimens, D4 is partly divided, and D4 and E9 appear as an elongated subhorizontal fossa (Fig. 4A). D3 is constantly distinct.

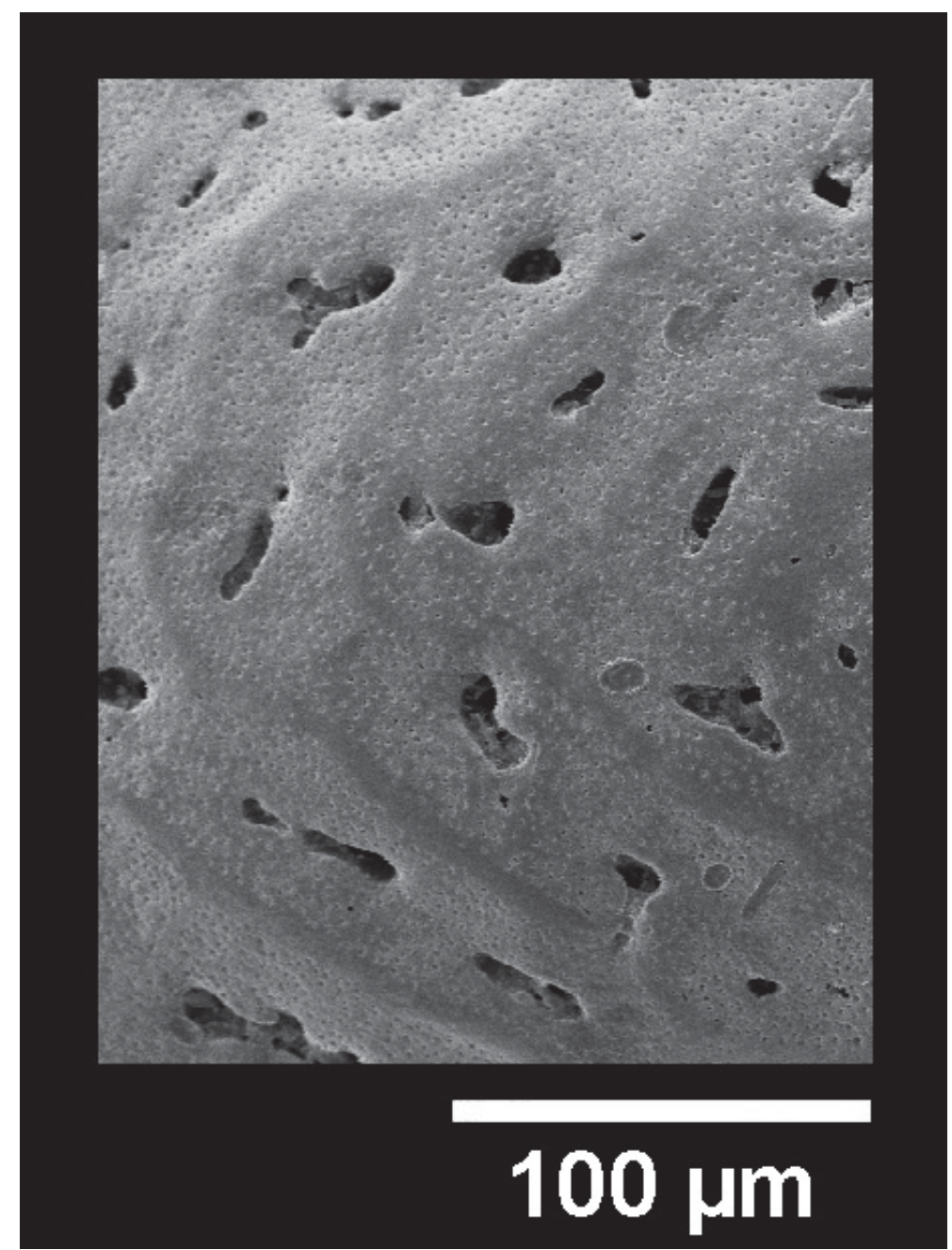

Fig. 7. Detail of papillae in heavily celated specimen of U. margaritifera (G.W. Müller, 1894), ABMC 2014/071. 
In U. ilariae sp. nov., the fossae D3-D4-E9 form a steady triangular pattern with D4-E9 fused and D3 is situated above them. In very rare celated specimens, D4 and E9 are distinct (Fig. 18G).

\section{d. Dorsal median group. Fossal pattern $\alpha 1-\alpha 6, \beta 1-\beta 5$}

In $U$. margaritifera/distinguenda, an ideal scheme of this group can be represented as two rows: the anterior row consists of six fossae, the posterior row includes five fossae, named $\alpha 1-\alpha 6$ and $\beta 1-\beta 5$ (Fig. 5A-F), respectively. This is seemingly in contrast with the scheme of Athersuch with $5+4$ fossae; in fact, the upper two fossae ( $\alpha 1$ and $\beta 1$ ), just below the post-ocular sinus, may be clearly observed in dorsal view (Fig. 19D). In lateral view they appear very reduced or even completely hidden (Figs 5E-F; 16H; 17B). In the posterior row, between the 4th ( $\beta 4)$ and 5th ( $\beta 5)$ fossa, a small smooth area, the "focus" of Athersuch (1977), is present. The lowermost fossae, herein named $\alpha 6$ and $\beta 5$, pertain, following Liebau's scheme (1971), to the E-ring encircling the muscle-scar node.

We observed the following variations:

- fossa $\alpha 3$ divided in two subfossae (Fig. 16F);

- fossa $\alpha 5$ divided in two (Fig. 16F, H) or three (Fig. 17F) subfossae;

- fossa $\alpha 6$ divided in two (Figs 5F; 17G);

- fossa $\beta 3$ partially connected with the centrodorsal fossae (Figs 16C; 17A).

The shape of the meshes shows a wide variability, partly due to celation, ranging from large rounded fossae to small pits, including narrow foveolae (Fig. 5A-F).

In U. ilariae sp. nov., the dorsal median group shows a different pattern (Fig. $5 \mathrm{G}-\mathrm{H}$ ). In comparison with the ideal scheme, the uppermost fossae $(\alpha 1, \beta 1)$ are absorbed in the post-ocular sinus; $\alpha 2$ and $\beta 2$ are located under the post-ocular sinus; $\alpha 2$ is alternatively isolated (Figs $5 \mathrm{G} ; 19 \mathrm{~B}$ ) or fused with $\beta 2$ (Fig. 18B). The fossa $\beta 2$, in turn, is fused with a posterior fossa (Figs $5 \mathrm{G} ; 19 \mathrm{~B}$ ). The $\alpha 3-\beta 3 / \alpha 4-\beta 4$ meshes may coalesce in part, generally forming a butterfly shaped quadruple fossa (Fig. $5 \mathrm{G}$ ); in some specimens $\alpha 4$ is fused with an anterior fossa (Fig. $5 \mathrm{H}$ ).

\section{e. Caudal group}

In U. margaritifera/distinguenda, it consists of a basic pattern of three well-defined fossae, two marginal and one internal with various shapes in different specimens (Fig. 6A-F). They may appear as a single triple fossa (Fig. 17H) or as a single plus one double fossa (Fig. 2A). In the latter case, anastomosis partially hides the identity of the fossae. Celation may completely obscure this pattern (Figs 6B; 17C).

In $U$. ilariae sp. nov., a fourth upper fossa $(\mathrm{Cg} 4)$ merges with the caudal group, forming a multiple L-shaped or elongated fossa; it can be more or less fused with another internal elongated multiple fossa (Fig. 6G-H).

Our observations indicate that the reticulation pattern in the forms previously attributed to U. margaritifera and $U$. distinguenda are identical. In $U$. ilariae sp. nov., well distinct patterns of homologous fossae can be recognized.

\section{Outline analysis}

The valve outline of $U$. margaritifera (i.e., U. margaritifera "morph margaritifera" plus $U$. margaritifera "transitional morph"), U. distinguenda (i.e., U. margaritifera "morph distinguenda") and U. ilariae sp. nov. were analysed and compared. In Fig. 8A-C the "non normalized area" (size dependent) mode results show that the variability of $U$. ilariae sp. nov. (Fig. 8A) is very limited. By contrast, in U. margaritifera (Fig. 8B) the variability is relatively wide, linked to the length of the valves. Conversely, with the "normalized area" (size independent) mode, a low variability is observed in U. margaritifera (Fig. 
9B) while it is relatively high in U. ilariae sp. nov. (Fig. 9A). U. distinguenda shows an intermediate variability in both modes (Figs 8C; 9C).

Comparisons of the mean outline of the three forms indicate that $U$. ilariae sp. nov. is positively separated from $U$. margaritifera and $U$. distinguenda, while the discrimination of the latter forms is difficult. In "normalized area" mode (Fig. 10B) U. ilariae sp. nov. shows a shorter length and a different shape in the caudal and in the anterodorsal regions. Its shorter length is more evident in the mean outlines deriving from "non normalized area" mode analysis (Fig. 10A).

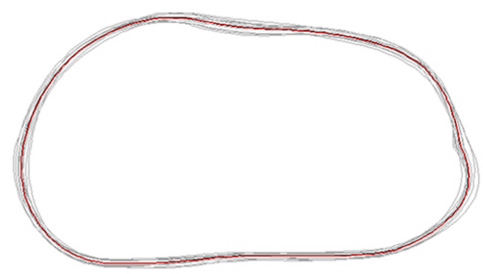

a

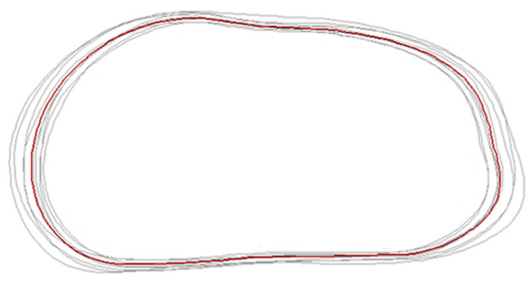

b

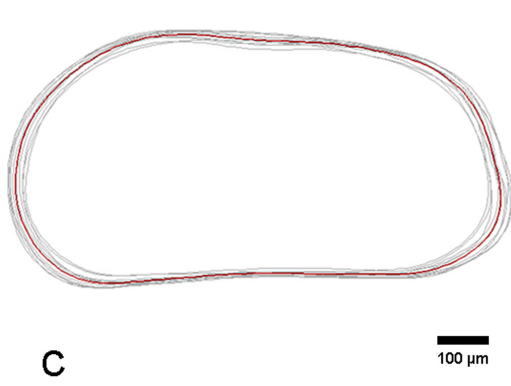

C

Fig. 8. Comparison of valve outlines obtained by Morphomatica analysis. Results for "non-normalized area" mode. A. U. ilariae sp. nov. B. U. margaritifera (G.W. Müller, 1894). C. U. distinguenda (Neviani, 1928).

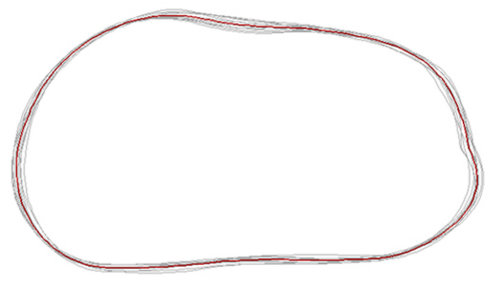

a

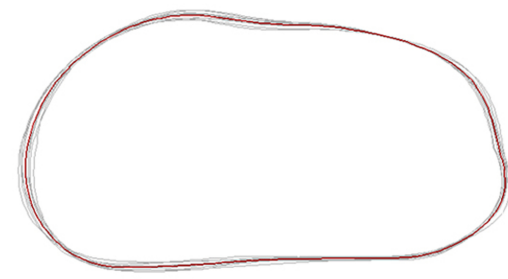

$\mathrm{b}$

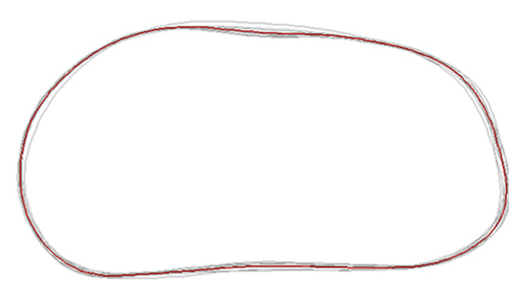

C

Fig. 9. Comparison of valve outlines obtained by Morphomatica analysis. Results for "normalized area" mode. A. U. ilariae sp. nov. B. U. margaritifera (G.W. Müller, 1894). C. U. distinguenda (Neviani, 1928).

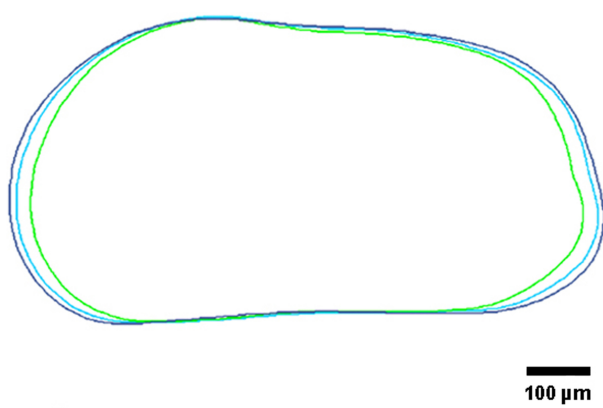

a

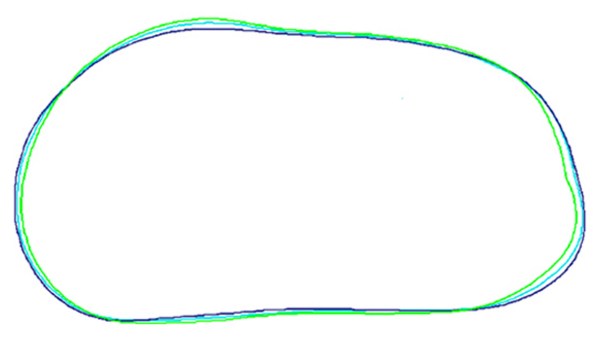

b

Fig. 10. Comparison of mean outlines of U. ilariae sp. nov. (green), U. margaritifera (G.W. Müller, 1894) (light blue) and $U$. distinguenda (Neviani, 1928) (dark blue) obtained by the Morphomatica analysis. A. Results for "non-normalized area" mode. B. Results for "normalized area" mode. 

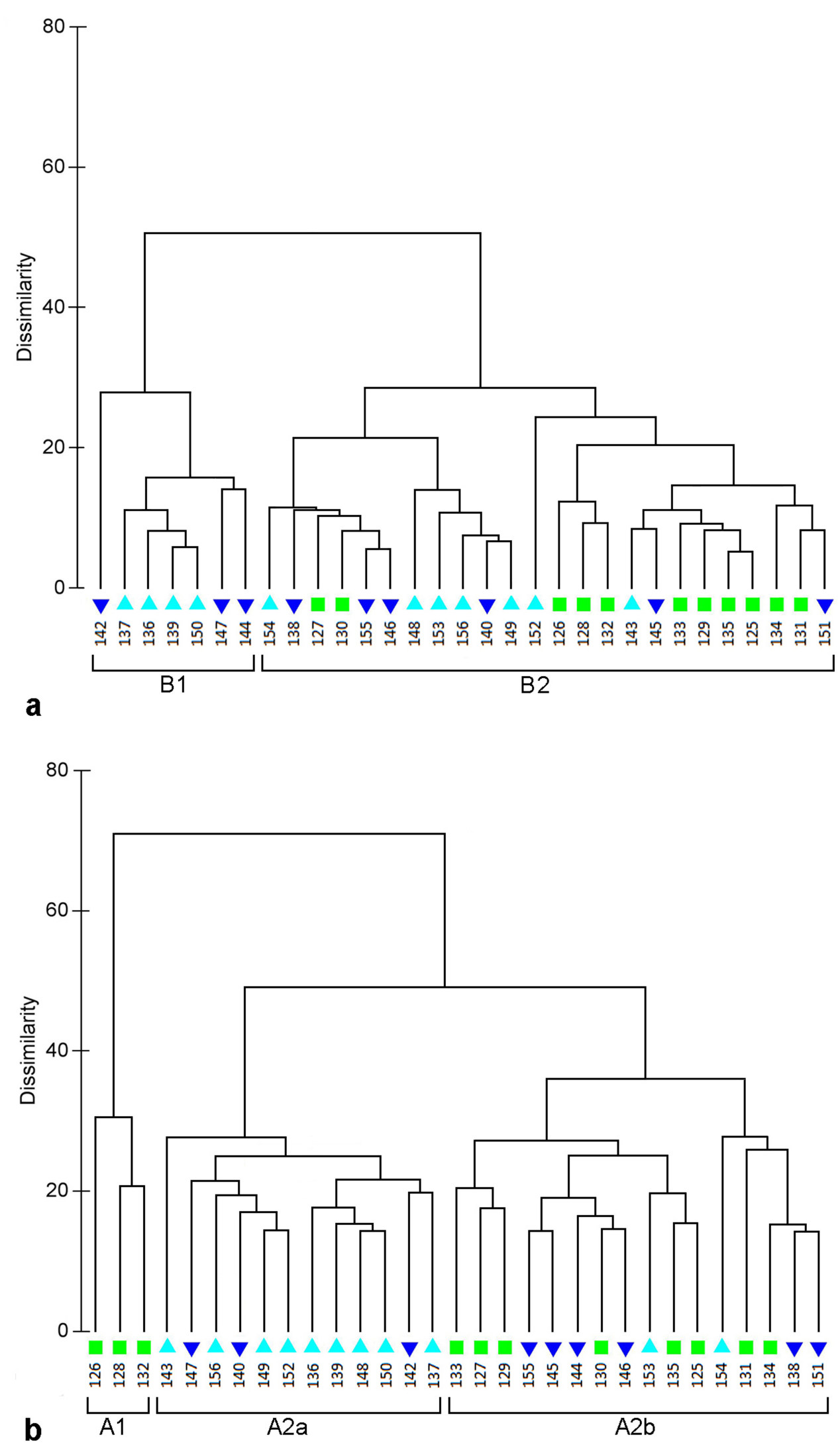

Fig. 11. Cluster analysis performed on valve outlines obtained by Morphomatica analysis. A. Dendrogram for "non-normalized area" mode. B. Dendrogram for "normalized area" mode. 
Cluster analysis for "normalized area" mode reveals two main clusters, the first (A1) includes three valves of $U$. ilariae sp. nov., the second (A2) consists of all the remaining specimens (Fig. 11B). This second cluster is subdivided into two subclusters: A2a, including nine valves pertaining to $U$. distinguenda and three specimens of $U$. margaritifera and $\mathrm{A} 2 \mathrm{~b}$, where all the three forms are present (eight $U$. ilariae sp. nov., two $U$. distinguenda and six U. margaritifera valves).

The "non normalized area" mode analysis (Fig. 11A) discriminates two main clusters: B1, consisting of three valves of $U$. margaritifera and four of $U$. distinguenda, and $\mathrm{B} 2$ including the remaining specimens.

The Anosim Pairwise Test applied both to the "non normalized area" (Fig. 12A) and "normalized area" mode (Fig. 12B) displays that $U$. ilariae sp. nov. and $U$. distinguenda are separated on the basis of the outline analysis $(\mathrm{R}=0.603 ; \mathrm{R}=0.628)$. Conversely, $U$. margaritifera cannot be discriminated from $U$. ilariae sp. nov. or from $U$. distinguenda.

N-Mps analysis provided comparable results (Fig. 13). The distribution areas of $U$. ilariae sp. nov. and $U$. distinguenda are well defined for both "non normalized area" mode (Fig. 13A) and "normalized area" mode (Fig. 13B), whereas the distribution of U. margaritifera specimens overlaps both U. ilariae sp. nov. and U. distinguenda.



a

\begin{tabular}{|l|c|c|}
\cline { 2 - 3 } \multicolumn{1}{c|}{} & $\mathrm{R}$ & $\mathrm{p}$ \\
\hline U.ilariae vs U.margaritifera & 0.104 & 0.078 \\
\hline U.ilariae vs U. distinguenda & 0.628 & 0.001 \\
\hline U.margaritifera vs U.distinguenda & 0.279 & 0.008 \\
\hline
\end{tabular}

b

Fig. 12. Analysis of similarities (One-way Anosim Pairwise Test). A. R statistic and p value for "nonnormalized area" mode. B. R statistic and p value for "normalized area" mode. 




a

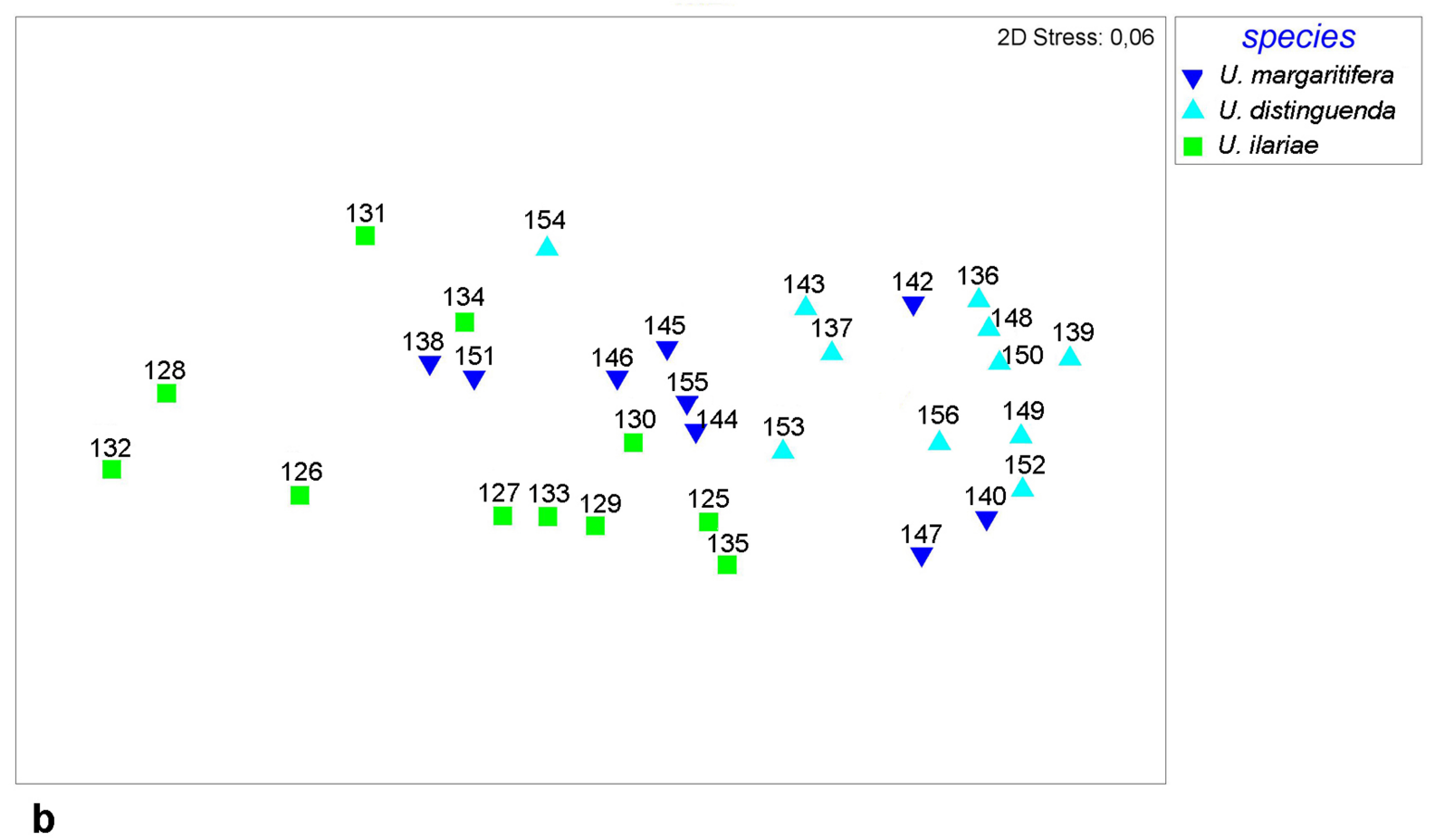

Fig. 13. Non-metric multidimensional scaling (n-MDS) analysis. A. Results for "non-normalized area" mode. B. Results for "normalized area" mode. 


\section{Taxonomy}

Classification follows Liebau (2005) and, for the attribution to subfamily, Hartmann \& Puri (1974).

Subclass Ostracoda Latreille, 1802

Superorder Podocopomorpha Kozur, 1972

Order Podocopida Sars, 1866

Suborder Cytherocopina Gründel, 1967

Infraorder Nomocytherinina Liebau, 1991

Superfamily Trachyleberidoidea Sylvester-Bradley, 1948

Family Hemicytheridae Puri, 1953

Subfamily Urocythereidinae Hartmann \& Puri, 1974

Genus Urocythereis Ruggieri, 1950

Urocythereis ilariae $\mathrm{sp}$. nov.

urn:1sid:zoobank.org:act:607A810F-773C-4F8F-91E7-D2EB5223CB7D

Figs 2B; 3G-H; 4G-H; 5G-H; 6G-H; 14; 18A-J; 19A-C, E-J

Urocythereis favosa (Roemer) n. ssp. Bassiouni, 1965: pl. 40, figs 8-9.

Urocythereis favosa (Roemer) subsp. - Wouters 1973: 385, pl. 2, fig. 7.

Urocythereis sp. - Bonaduce, Ciampo \& Masoli 1976: 46, pl. 22, fig. 9.

? Urocythereis sp. - Athersuch 1977: pl. 17, fig. 2.

Urocythereis aff. U. favosa (Roemer) - Arbulla, Pugliese \& Russo 2001: fig. 3t.

? Urocythereis sp.1 - Barra 1997: 82, pl. 4, fig. 6.

Urocythereis sp.1 - Aiello et al. 2006: tables 3, 10. — Aiello, Barra \& Parisi 2013: fig. 1d.

\section{Diagnosis}

A large reticulate species of Urocythereis, subrectangular in lateral view, inflated-ovate in dorsal view. Reticulum with large polygonal-rounded, frequently coalescing, large fossae separated by broad muri. In the anteroventral area the muri form distinct riblets running parallel to the margin.

\section{Etymology}

In honour of our friend and collegue Ilaria Mazzini, in recognition of her important contribution to ostracodology.

Type material (4 carapaces, 43 valves: 29 adults and 14 juveniles)

Holotype

IONIAN SEA: ABMC 2014/03

Paratypes

IONIAN SEA: ABMC2 014/026-036, ABMC 2014/038, ABMC 2014/042, ABMC 2014/044, ABMC 2014/046-049, ABMC 2014/063-064, ABMC 2014/069, ABMC 2014/072-073, ABMC 2014/080, ABMC 2014/097-103, ABMC 2014/120-135.

\section{Stratum typicum}

Recent. 
AIELLO G. et al., Shell variability of Urocythereis in the La Strea Bay (Italy)

\section{Locus typicus}

La Strea Bay (Porto Cesareo Lagoon), Southern Italy, Ionian Sea, sampling station E4, 1754'25" N, $40^{\circ} 15^{\prime} 59^{\prime \prime}$ E, depth $1.5 \mathrm{~m}$ bsl.

\section{Description}

Measurements (holotype): LV: $\mathrm{L}=0.85 \mathrm{~mm}, \mathrm{H}=0.44 \mathrm{~mm}$ (Fig. 18A).

Large $(\mathrm{L}=0.85-0.90 \mathrm{~mm})$ species of Urocythereis, characterized by large fossae and strongly developed muri, subrectangular in lateral view, inflated-ovate in dorsal view. Valves strongly calcified and thick. Dorsal margin gently, unevenly convex, ventral margin weakly sinuous; anterior end broadly rounded, denticulate in the lower part; upper part of the posterior margin concave, lower part of the posterior margin convex, variably denticulate, forming short blunt caudal process located below mid-height. Maximum height at anterior cardinal angle, greatest length below mid-height. Surface of valves coarsely reticulate. Fossae, showing subrounded or irregular shape, coalesce, especially in marginal areas, forming both multiple anastomized elongated fossae and deep sulci parallel to margin. The corresponding muri tend to form a system of concentric riblets. Marginal rim starts from anterior part of dorsal margin, behind eye tubercle (Fig. 19C), and ends in posteroventral angle. Second riblet, constantly well developed, runs parallel to margin of valve except posterior end. This ocular riblet is connected with eye tubercle and rises above dorsal margin. Marginal rim and second riblet not connected. Third riblet, irregularly developed, delimits anteriorly the reticulum stricto sensu from subocular area to posterior part of ventral area and is connected with second riblet anteriorly, at mid height, through single radial murus; in the ventral area second and third riblets converge and, in lateral view, they seem apparently to be connected, but ventral view (Fig. 19A) shows they remain separate. The fossae between second and third riblet mainly anastomized. Fourth riblet fully part of reticulum, and shows a rather regular parallel trend only in anterocentral area. Surface of central area irregularly reticulate with subrounded/polygonal fossae with a low degree of anastomosis. Conversely, fossae located in proximity of caudal process coalesce following a longitudinal trend. Rare specimens show celation, never fully developed. Muri smooth, not papillate (Fig. 19E).

Hinge holamphidont (sensu Scott 1961): in left valve posterior hinge socket elongate and curved; anterior element formed by ovate-rounded (or elongate) tooth and elongate socket; median bar smooth; its posterior thickening forms, in some cases, barely defined toothlet; right valve hinge complementary, with faintly crenulate teeth (Figs 18I-J; 19G-J).

Inner lamella, marginal pore canals and muscle scar pattern (Fig. 19F) characteristic of genus (details in Athersuch 1977).

\section{Distribution}

The species occurs in the Recent of the Mediterranean: Gulf of Naples (Bassiouni 1965), Sardinia (Arbulla et al. 2001), South Adriatic Sea (Bonaduce et al. 1976) and possibly Libya (see section Remarks); it has previously been recorded in fossil associations from the Tyrrhenian (upper Pleistocene) of Tunisia only (Wouters 1973). Distribution data are summarized in Fig. 14.

\section{Remarks}

U. ilariae sp. nov. has previously been assigned to U. favosa (Bassiouni 1965; Wouters 1973), type species of the genus Urocythereis (neotype figured by Athersuch 1977). The reticulation of $U$. favosa differs from that of $U$. ilariae sp. nov. in the different style of fossal anastomosis. This is mostly evident, for example, in the anterodorsal zone, where the continuous depressed area formed by the fossal pattern C1-C2/B1-B4 is present in U. ilariae sp. nov. and absent in the Pliocene species. 
The shell characters of $U$. exedata, described by Uliczny (1969) as a subspecies of $U$. favosa (SEM micrographs in Mostafawi \& Matzke-Karasz 2006), show a close resemblance to those of $U$. ilariae sp. nov., especially in the structure of the ocular riblet, homologous to Bradleya's "ocular ridge" (Benson 1972). The Pliocene species probably represents an ancestor of the living form. The two species differ in some reticulum features. In the anteroventral area of $U$. ilariae sp. nov. the third and the fourth riblets are connected ventrally and anteriorly; consequently they delimit the merged $\mathrm{C}$ fossae, forming an anteroventral furrow enclosed by muri. Conversely, in U. exedata the anteroventral area is characterized

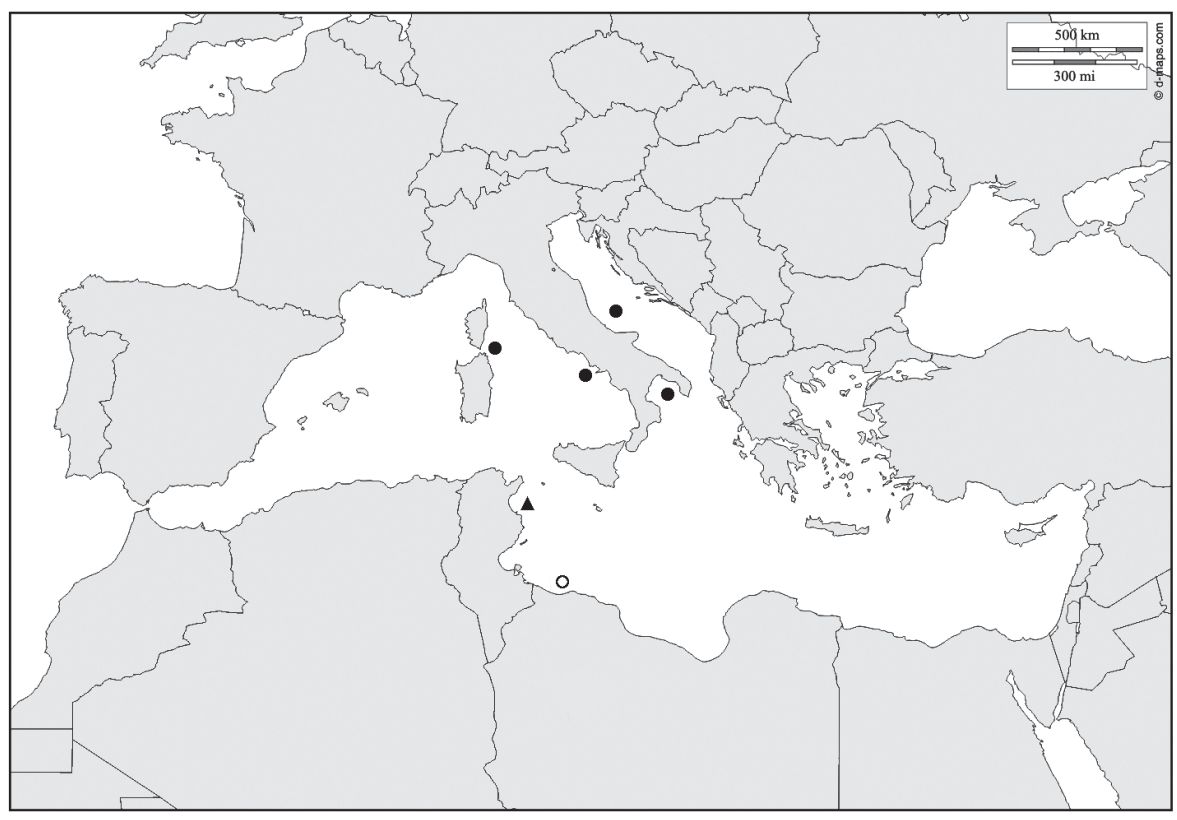

a

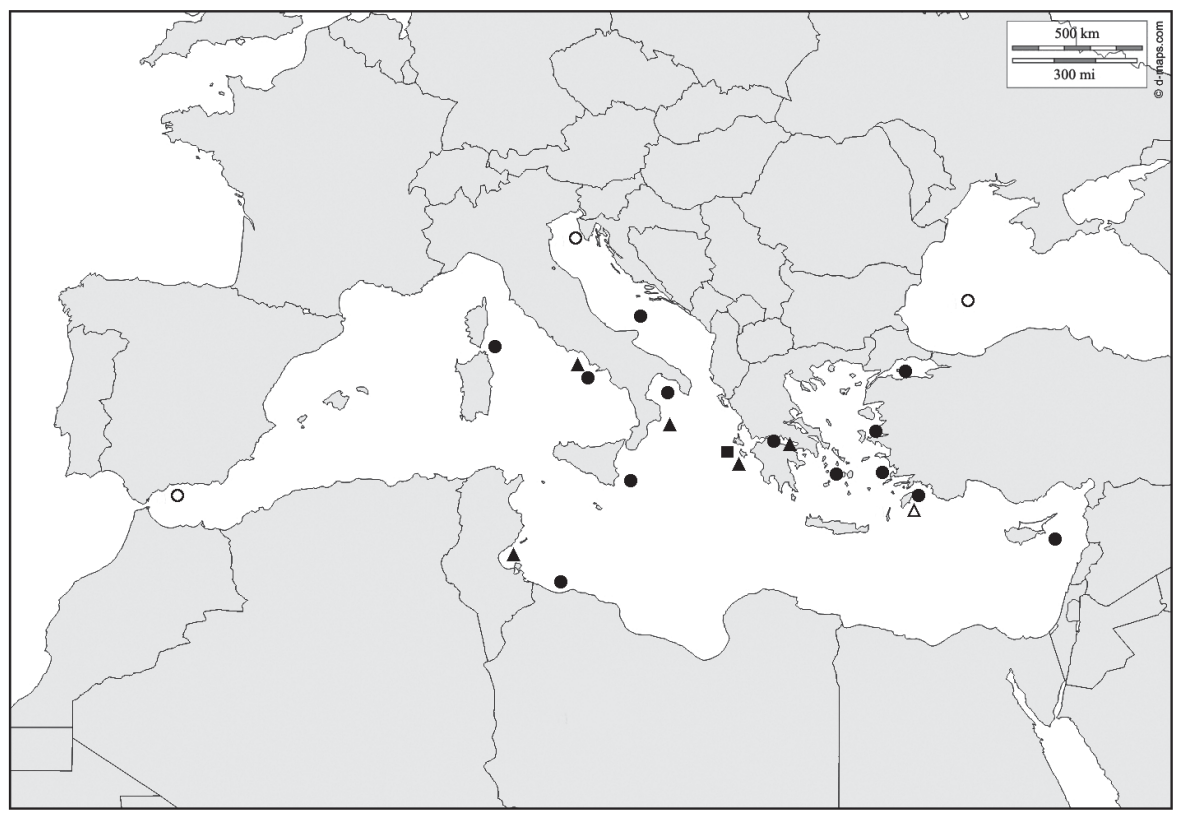

b

Fig. 14. Distribution of U. ilariae sp. nov. and U. margaritifera (G.W. Müller, 1894). Circles = Recent; triangles $=$ Pleistocene; squares $=$ Pliocene; filled $=$ certain; empty $=$ uncertain. 
by a segment of the third riblet encircled by an elongated ring made up of $\mathrm{B}$ and $\mathrm{C}$ anastomized fossae, anteriorly and ventrally connected. In the anterodorsal area of $U$. ilariae sp. nov., the third concentric riblet is more or less developed in different specimens (Figs 2B; $18 \mathrm{D}, \mathrm{F}$ ), while in $U$. exedata in the anterodorsal area the fossae of the $\mathrm{B}$ group coalesce with $\mathrm{C}$ and $\mathrm{D}$ fossae, the muri follow a radial trend and consequently the third concentric riblet is virtually absent.

The assignment of the North-African form, figured by Athersuch (1977) as Urocythereis sp. and by Barra (1997) as Urocythereis sp. 1, to U. ilariae sp. nov. needs further investigation. At the current state of knowledge we are inclined to interpret the morphological differences between the central Mediterranean species and the Lybian deme as the beginning of an allopatric speciation.

Urocythereis margaritifera (G.W. Müller, 1894)

Figs 2A; 3A-F; 4A-F; 5A-F; 6A-F; 16A-K; 17A-J; 19D

Cythere oblonga Brady, 1866: 353, pl. 59, figs 5a-d (non C. oblonga M'Coy, 1844).

Cythereis margaritifera G.W. Müller, 1894: 368, pl. 32, figs 26, 29, 32, 35-37.

Cythereis (Auris) distinguenda Neviani, 1928: 105 (synonymy only) (non p. 105 description and pl. 2, figs 91-93).

Urocythereis margaritifera alba Uliczny, 1969: 65, pl. 15, fig. 9.

Urocythereis sp. Athersuch, 1977: pl. 17, fig. 5.

Urocythereis sp. 2 Barra, 1997: 82-83, pl. 4, fig.8.

Urocythereis sp. 3 Barra, 1997: 83, pl. 4, fig. 11.

Hemicythere (Urocythereis) margaritifera - Ruggieri 1953: 94, pl. 6, fig. 1.

Urocythereis britannica Athersuch - Kubanc 1995: 32-33, pl. 8, figs 4a-b.

Urocythereis crenulosa (Terquem) - Mostafawi \& Matzke-Karasz 2006: pl. 6, fig. 9 (non pl. 8, fig. 1; non Cythere crenulosa Terquem, 1878).

Urocythereis distinguenda - Athersuch 1977: 257, 259, pl. 7, figs 1-6; pl. 8, figs 1-6; pl. 9, figs 1-5; pl. 12, figs 5-6; figs 3c-d. — Athersuch 1979: fig. 2.19. - Aiello et al. 2006: tabs. 3, 7, 10. — Aiello, Barra \& Parisi 2013: fig. 1 b.

Urocythereis favosa (Roemer) - Barbeito-Gonzalez 1971: 279, pl. 13, figs 1b, 3b, 4b, 6b, pl. 46, figs 2427 (non pl. 13, figs 2b, 5b, pl. 46, figs 28-29). - Doruk 1974: pl. 38, fig. 3, pl. 40, figs 1-3 (non pl. 34, figs 1-2, pl. 38, figs 1-2). — Puri 1974: pl. 13, fig. 3. — Tunoglu 1999: pl. 7, fig. 1.

Urocythereis aff. U. favosa-Bonaduce, Ciampo \& Masoli 1976: 45, pl. 22, fig. 8 (sic fig. 7).

? Urocythereis favosa - Triantaphyllou, Tsourou, Koukousioura \& Dermitzakis 2005: pl. 3, fig 11.

Urocythereis margaritifera - Athersuch 1977: 260, 262, pl. 12, figs 1-4; pl. 13, figs 1-6; pl. 14, figs 1-5; figs 3e-f. - Tsapralis 1981: 100, pl. 1, fig. 1. — Lachenal 1989: 175-176, pl. 3, fig. 14. — Kubanç 1995: 31-32, pl. 8, figs 3a-c. - Aiello et al. 2006: tabs. 3, 5. - Perçin-Paçal \& Balkis 2012: pl. 2, fig. 3. - Aiello, Barra \& Parisi 2013: fig. 1a.

? Urocythereis margaritifera - Aranki 1987: 72, pl. 19, figs 5-7. — Stancheva 1989: pl. 2, fig. 9. Şafak, Avşar \& Meriç 1999: pl. 3, fig. 12.

Urocythereis cf. U. margaritifera - Arbulla, Pugliese \& Russo 2001: fig. 3s.

Urocythereis? margaritifera - Aiello, Barra \& Parisi 2013: fig. 1c.

Urocythereis margaritifera alba - Breman 1976: 63-64, pl. 9, fig. 124. — Aiello, Barra, De Pippo \& Donadio 2012: pl. 2, fig. 8.

? Urocythereis margaritifera alba - Uffenorde 1972: 79, pl. 8, fig. 9.

Urocythereis margaritifera margaritifera - Uliczny 1969: 65, pl. 15, fig. 8.

? Urocythereis margaritifera margaritifera - Sissingh 1972: 128, pl. 10, fig. 8.

Urocythereis seminulum (Seguenza) - Şafak, Avşar \& Meriç 1999: pl. 3, fig. 11.

Urocythereis sp. - Mostafawi, 1994: 107, pl. 7, fig. 6. 


\section{Distribution}

The species is widely distributed in the infralittoral waters of the Eastern Mediterranean (Brady 1866; Barbeito-Gonzalez 1971; Doruk 1974; Athersuch 1977, 1979; Kubanç 1995; Tunoglu 1999; PerçinPaçal \& Balkis 2012), the Tyrrhenian Sea (G.W. Müller 1894; Puri 1974) and the southern Mediterranean (Athersuch 1977; Lachenal 1989; Barra 1997). Recordings from the Black Sea are uncertain: the specimen figured by Stancheva (1989) is a young instar, and Schornikov (1969) reported Müller's original drawings. The species is present in the southern part of the Adriatic Sea; the findings in the central and northern Adriatic are doubtful (Uffenorde 1972; Bonaduce et al. 1976; Breman 1976).

Fossil specimens have been reported from the Upper Pleistocene-Holocene of the Gulf of Gabès (Lachenal 1989), the Pleistocene of Southern Italy (Ruggieri 1953; Aiello et al. 2012), Zakynthos (Tsapralis 1981), the Northern Peloponnesus (Mostafawi 1994) and, possibly, Rhodes (Sissingh 1972) and from the Pliocene of Cephalonia (Uliczny 1969). Distribution data are summarized in Fig. 14.

The presence of the species in Miocene sediments (Şafak et al. 1999) has to be confirmed by further studies.

\section{Remarks}

The analysis of the shell features of the Urocythereis population in the La Strea Bay and comparisons with the literature have convinced us that $U$. margaritifera and $U$. distinguenda $(=U$. oblonga $)$ are two morphotypes of the same species. In particular, we consider the latter "species" as the celated variation of the former. Celation is not expressed homogeneously on the valves in all the specimens; consequently, also "transitional" shells show different morphs.

The original illustration by Müller (1894: pl. 32, fig. 26) shows anteroventral fossae horizontally merged; the lectotype reported by Athersuch (1977: pl. 13, fig. 2) and the Libyan specimen figured by Barra (1997, as $U$. sp. 2) shows the same feature. Presently, we do not regard this character as diagnostic, due to the observed variability.

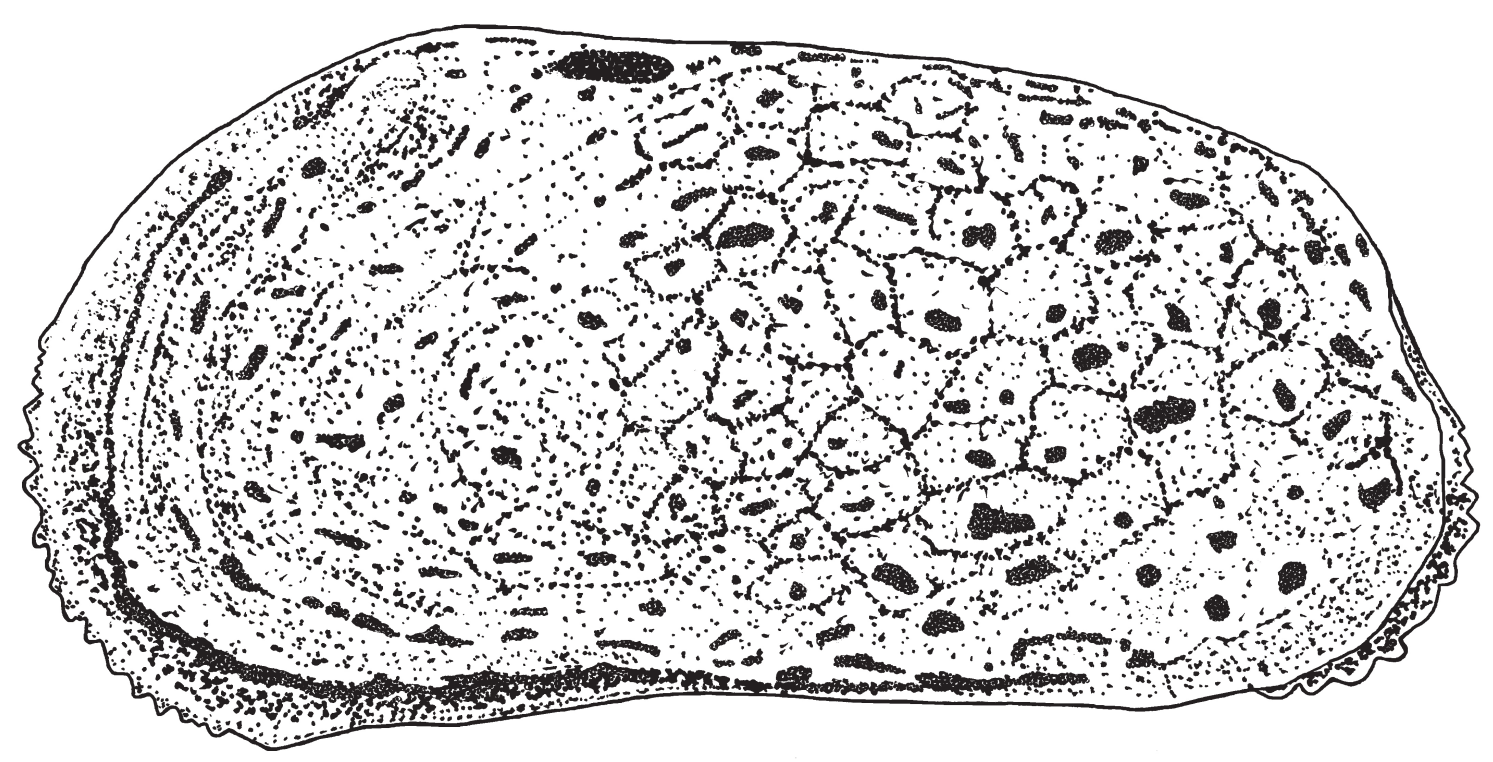

Fig. 15. Scheme of the hidden reticulation evidenced in a celated specimen, LV, sample E6, ABCM 2014/053. Same specimen as Fig. 16G. 
AIELLO G. et al., Shell variability of Urocythereis in the La Strea Bay (Italy)

Athersuch (1977) figured some appendages, including the right copulatory appendage, of $U$. distinguenda and the left copulatory appendage of $U$. margaritifera. Regarding the discrimination of the two species, the author stated that in U. margaritifera the ductus ejaculatorius is short and is contained within the area of the appendage, whereas in $U$. distinguenda the duct is much longer and passes beyond the ventral margin. Examination of Athersuch's illustrations (figs 4.d; 5.i) and a comparison with Müller's drawing of the male copulatory appendage of Cythereis margaritifera (pl. 32, fig. 32) show that only very subtle differences are present and they represent, in our opinion, intraspecific variations.

The maximum mesh size is reached in the subspecies Urocythereis margaritifera alba Uliczny, 1969. This form, in which celation is not developed, does not occur in the La Strea Bay. In some specimens the SEM micrographs revealed a feeble trace of the muri underlying the secondary calcification, as shown in Fig. 15. The comparison of this hidden reticulation with the specimens figured by Uliczny (1969), Breman (1976) and Aiello et al. (2012) suggests that U. m. alba is a non-celate morphotype of U. margaritifera. The North Adriatic form figured by Uffenorde (1972) (very similar to the Pliocene specimen figured by Şafak et al. 1999 as U. margaritifera) shows some tiny differences in the reticulation pattern and the assignment to U. margaritifera is queried.

The Libyan form figured by Athersuch (1977: pl. 17, fig. 5) as $U$. sp. and by Barra (1997) as U. sp. 3 fits the U. margaritifera morph c (Fig. 17E) well.

The left valve, figured by Aranki (1987) from the western Mediterranean shallow waters, shows some minor differences in the reniform outline and in some details of the reticulum. The relationships between Mediterranean and Atlantic forms (i.e., between U. margaritifera and U. britannica, frequently reported as $U$. oblonga) need further investigations.

Ruggieri (1953) hypothesized that $U$. favosa and $U$. margaritifera might be conspecific, the latter species representing a subspecies of the former. In spite of the similarity of the two forms, some features of the reticulum seem to allow a separation of the two species. In U. favosa (neotype figured in Athersuch 1977) the fossae B3 and B4 are merged, as well as C3 and C4; in U. margaritifera they are distinct; in $U$. favosa the fossae D2-D1 and $\alpha 4$ coalesce while in U. margaritifera they are distinct. In the caudal group the fossa $\mathrm{Cg} 4$ in $U$. margaritifera is separate, whereas in $U$. favosa the arrangement of the fossae is similar to that in U. ilariae sp. nov. In the La Strea Bay, and possibly in the Recent of the Mediterranean, U. favosa s.s. is not recorded and we prefer to retain them as separate species.

Some Urocythereis spp. from the Pliocene of Rhodes have been described by Terquem (1878) and figured by Mostafawi (1989). They are distinct from U. margaritifera in some characters of the reticulum. By contrast, the specimen from Cephalonia figured by Mostafawi \& Matzke-Karasz (2006) as U. crenulosa fits well with some specimens of $U$. margaritifera from Porto Cesareo.

The Atlantic forms reported as U. britannica and (erroneously) as U. oblonga (e.g., Guillaume et al. 1985; Ruiz et al. 2006) show a high variability and a complex affinity with $U$. margaritifera and $U$. favosa and they have not been considered in the present study.

\section{Discussion}

The comparison of five selected fossae-muri homologous groups convinced us that at present two species of Urocythereis live in the Porto Cesareo Lagoon and not three as previously reported by Aiello et al. $(2006,2013)$. Reticulum analysis demonstrates that the ornamentation patterns of $U$. margaritifera and $U$. distinguenda (sensu Aiello et al. 2006) are basically identical, and that the differences between morphs are similar, for example, to the continuous (non-polymorphic s.s.) variations described by Neil (2000) for the hemicytherid species Chapmanella flexicostata (Chapman, 1914). 


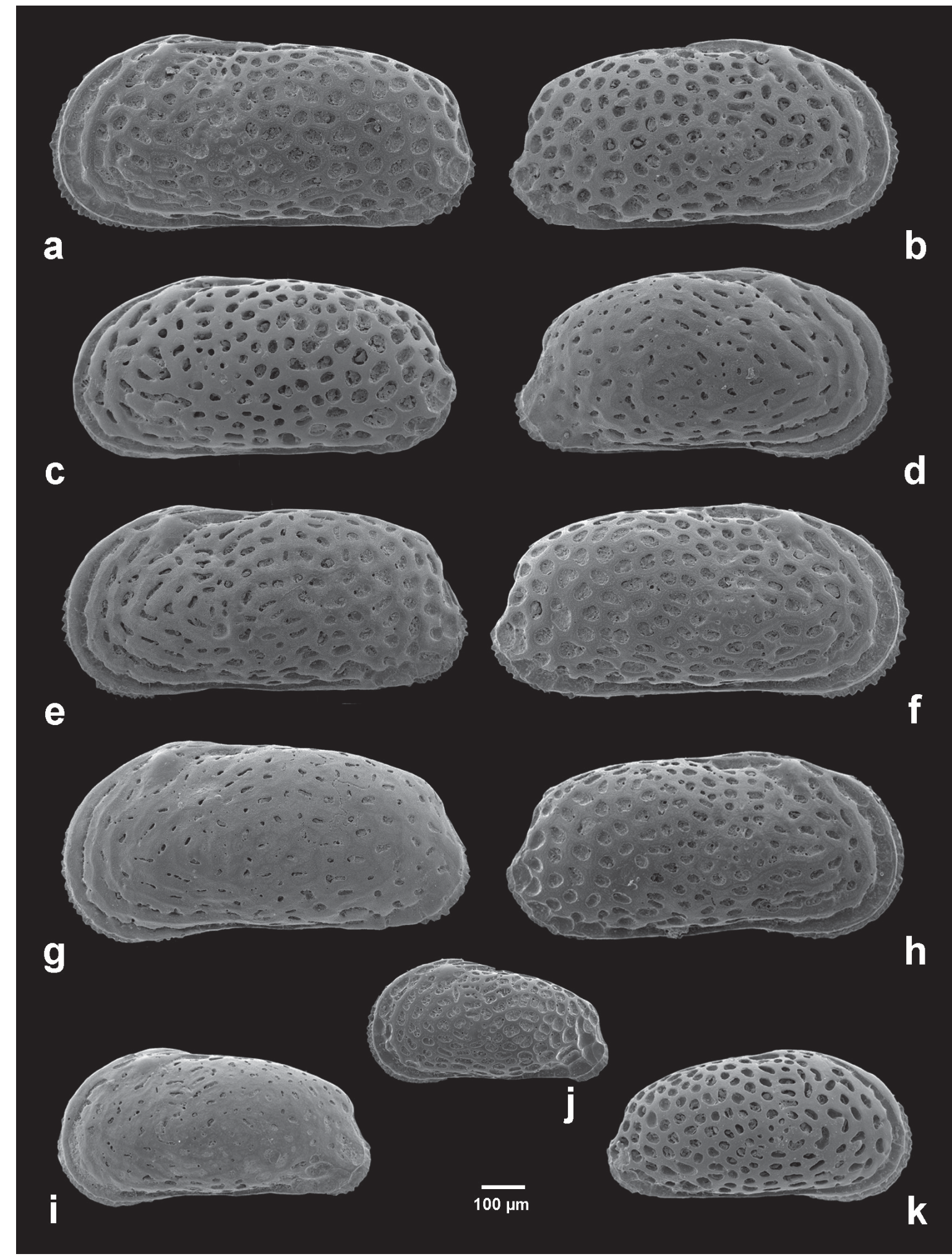

Fig. 16. U. margaritifera (G.W. Müller, 1894). A. LV, sample E4, ABCM 2014/037. B. RV, sample E4, ABCM 2014/040. C. LV, sample A2, ABCM 2014/083. D. RV, sample E4, ABCM 2014/039. E. LV, sample D3, ABMC 2014/075. F. RV, sample E4, ABCM 2014/041. G. LV, sample E6, ABCM 2014/053. H. RV, sample H, ABCM 2014/065. I. LV (A-1 instar), sample E6, ABCM 2014/054. J. LV (A-2 instar), sample D3, ABCM 2014/114. K. RV (A-1 instar), sample A2, ABCM 2014/056. 


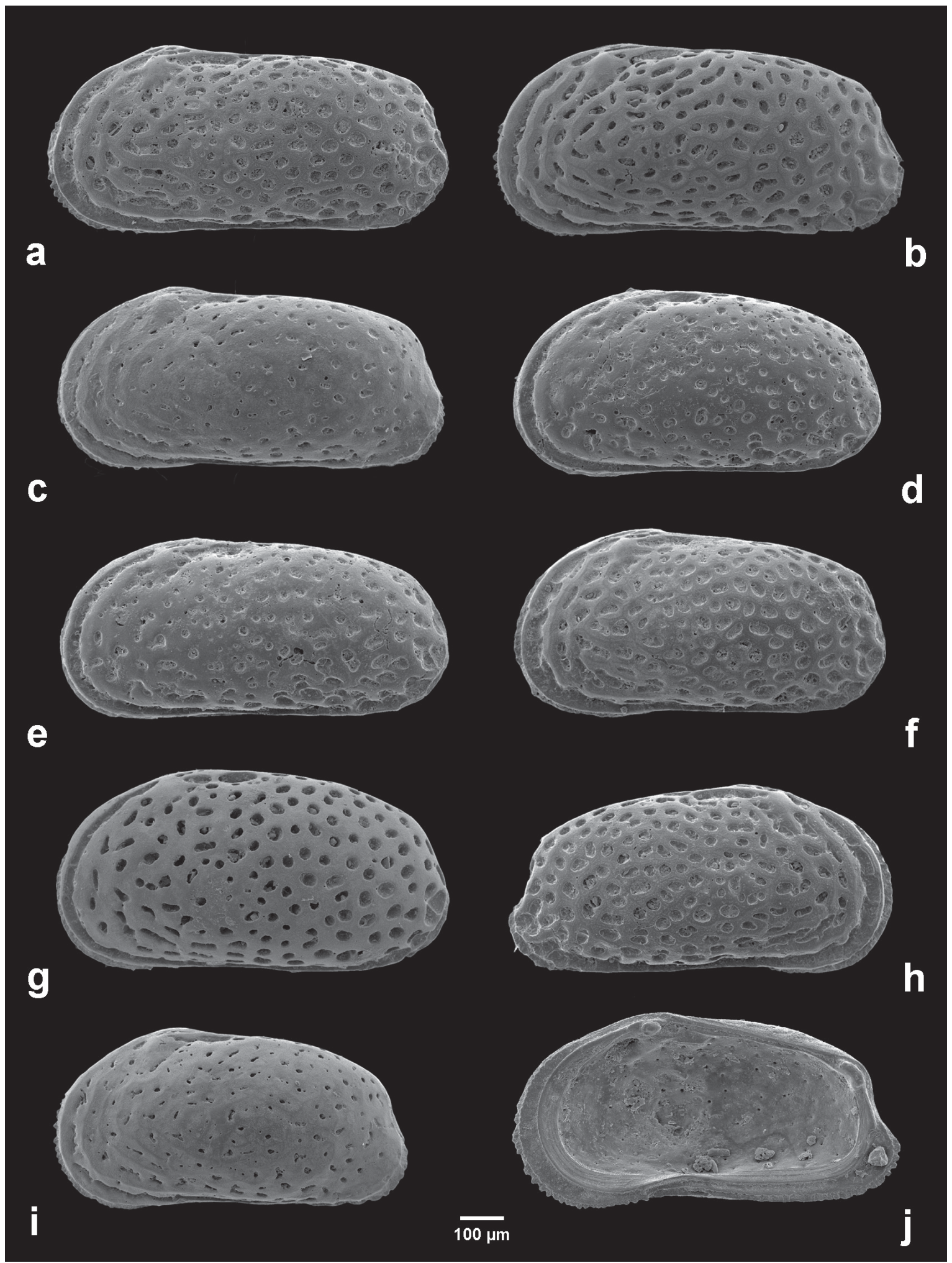

Fig. 17. U. margaritifera (G.W. Müller, 1894). A. LV, sample E6, ABCM 2014/045. B. LV, sample B3, ABCM 2014/059. C. LV, sample E6, ABCM 2014/050. D. LV, sample B3, ABCM 2014/062. E. LV, sample A2, ABCM 2014/055. F. LV, sample H, ABCM 2014/070. G. LV, sample B2, ABCM 2014/058. H. RV, sample H, ABCM 2014/066. I. LV, sample H, ABMC 2014/071. J. RV, internal view, sample E6, ABMC 2014/052. 


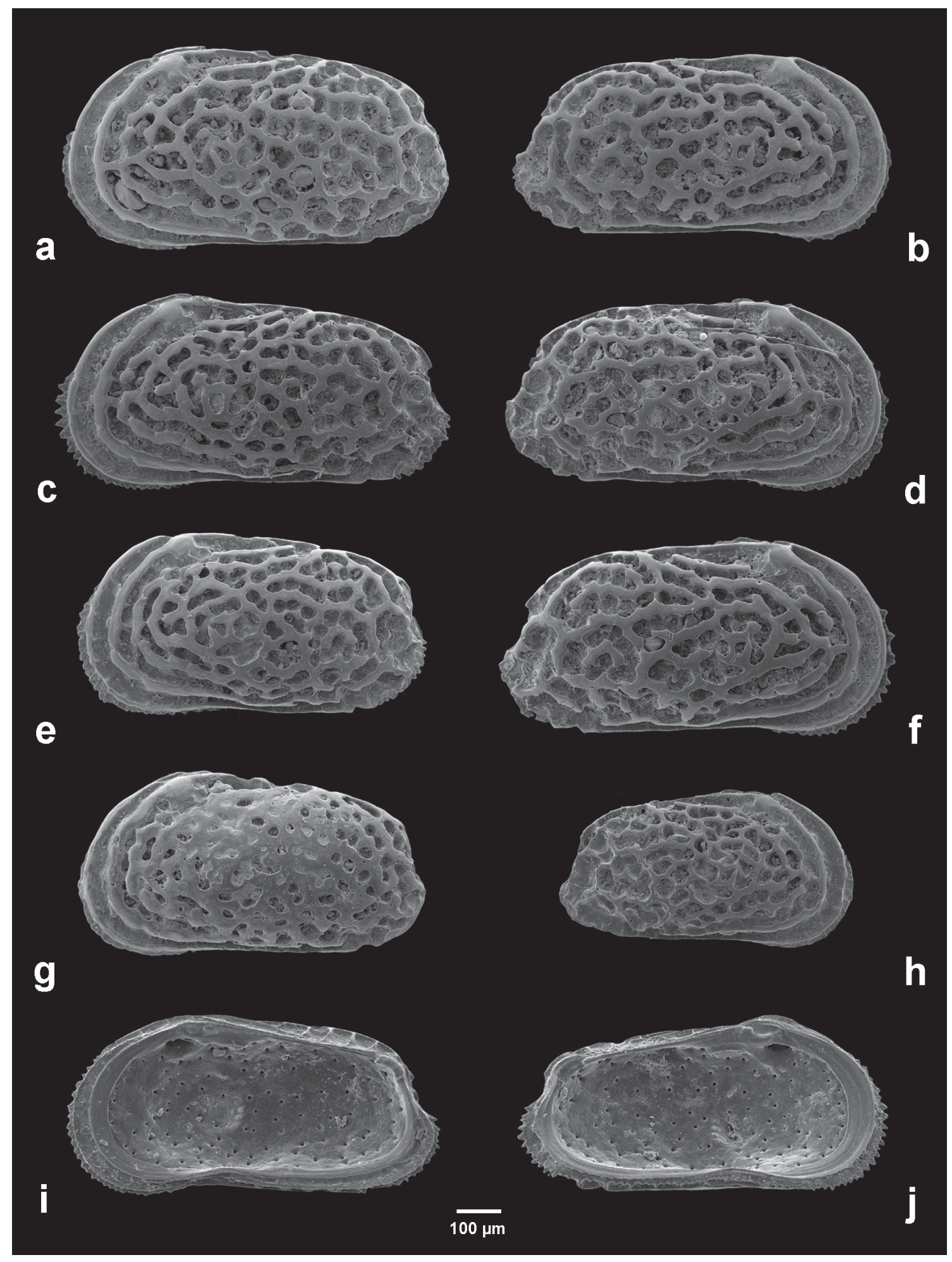

Fig. 18. U. ilariae sp. nov. A. Holotype, LV, sample E4, ABMC 2014/038. B. Paratype, RV, sample E4, ABMC 2014/044. C. Paratype, LV, sample E6, ABMC 2014/028. D. Paratype, RV, sample E4, ABMC 2014/036. E. Paratype, LV, sample H, ABMC 2014/069. F. Paratype, RV, sample E5, ABMC 2014/030. G. Paratype, LV, sample E5, ABMC 2014/032. H. Paratype, RV, (A-1 instar), sample D3, ABMC 2014/121. I. Paratype, RV, internal view, sample E4, ABMC 2014/033. J. Paratype, LV, internal view, sample E4, ABMC 2014/034. 


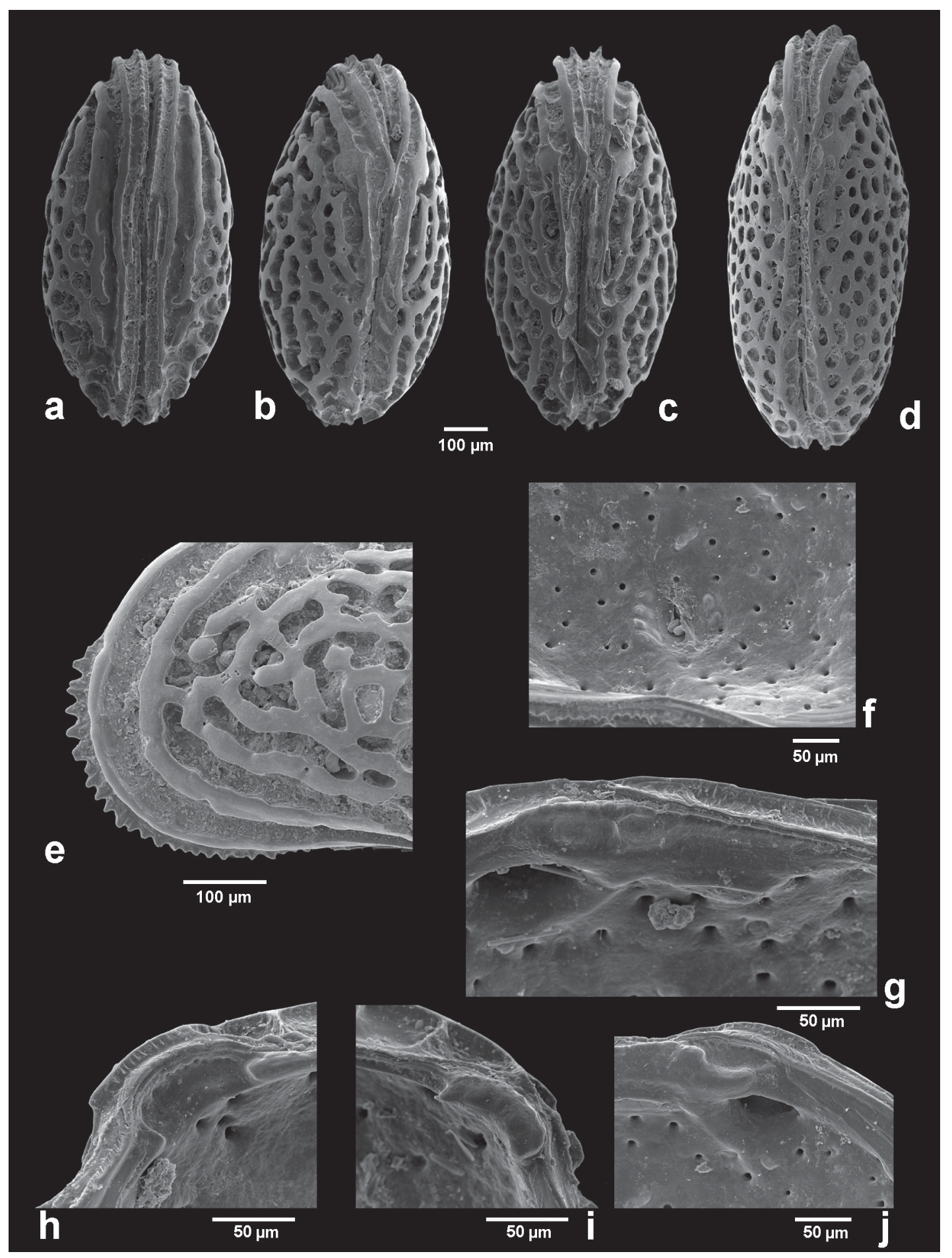

Fig. 19. - A-C, E-J. U. ilariae sp. nov. A. Paratype, C in ventral view, sample G2, ABCM 2014/26. B. Paratype, C in dorsal view, sample D3, ABCM 2014/80. C. Paratype, C in dorsal view, sample F3, ABCM 2014/27. E. Paratype, LV, sample E6, ABMC 2014/028. F. Paratype, LV, detail of muscle scars, sample E4, ABMC 2014/034. G. Paratype, RV, detail of the anterior part of the hinge, sample E4, ABMC 2014/033. H. Paratype, LV, detail of the posterior part of the hinge, sample E4, ABMC 2014/034. I. Paratype, RV, detail of the posterior part of the hinge, sample E4, ABMC 2014/033. J. Paratype, LV, detail of the anterior part of the hinge, sample E4, ABMC 2014/034 - D. U. margaritifera (G.W. Müller, 1894), C in dorsal view, sample C1, ABCM 2014/060. 
Our observations confirm only partly Athersuch's statement that celation is present exclusively in adult individuals of Urocythereis. Actually, we have recorded a few penultimate instars showing a certain degree of celation (Fig. 16I, K). In young A-2 instars, celation is not recorded or is very poorly developed (Fig. 16J).

The results of the morphometric analysis by means of the Morphomatica program need further interpretation.

The Anosim Pairwise Test and n-Mds analysis confirm that the outlines of U. margaritifera and $U$. distinguenda cannot be discriminated, as showed by the reticulum analysis, supporting the idea that they are different morphs of the same species. Furthermore, the Anosim Pairwise Test and n-MDs analysis display a clear separation between U. ilariae sp. nov. and U. margaritifera "morph distinguenda", while they are not able to discriminate between U. ilariae sp. nov. and U. margaritifera "morph margaritifera", in spite of the evidence that they show different specific reticulation features, due to the wide outline variability of the latter form.

By contrast, the comparison of the mean outlines derived from the "non normalized area" mode allows the discrimination between $U$. ilariae sp. nov. and U. margaritifera s.l.

We interpret the peculiar distribution of $U$. ilariae sp. nov. and celated U. margaritifera ("morph distinguenda") in two different ways. The first is to separate them, due to the obvious attribution to a different species showing a relatively low variability in outline and reticulation. On the other hand, the distribution of $U$. margaritifera "morph distinguenda" needs a different explanation. We suggest that the outlines of celated specimens show a certain degree of separation due to the secondary calcification of the valves. According to the Van Morkhoven's investigations (1962), in specimens of Cypris pubera a rich calcium diet induced secondary thickening of the shell. The morphological alterations developed to such a point that, in the author's words, "most likely they would have been classified as a distinct species, if the history of the individuals had not been known".

In some Urocythereis species, the age effect could somewhat replace the food-related secondary calcification observed by Van Morkhoven.

Our favourite solution to the "U. margaritifera - U. distinguenda problem" is to consider the distinguenda morph as the result of a supposed gerontic process, possibly in waters supersaturated with $\mathrm{CaCO}_{3}$ (see Peypouquet et al. 1988, and references therein), which caused both celation and a slight outline modification, partly recognized by Morphomatica.

The presence of celation in juveniles seems to contradict this interpretation, nonetheless it has been considered that the presence of long A-2 and A-1 stages duration has been recorded, as for example by Hagerman (1969) in Hirschmannia viridis (O.F. Müller, 1785). We suggest that overwintering juveniles (Horne 1983 and references therein) could in some cases develop the same gerontic features as the adults.

\section{Conclusions and additional remarks}

In the present investigation we attempted to examine the variability of the Urocythereis shell characters of the species occurring in the La Strea Bay. Our results show that we deal here with two species: $U$. ilariae sp. nov., displaying a low variability and a low degree of celation, and $U$. margaritifera, a species with a high (continuous, non polymorphic) variability and able to express intense celation. The specific name $U$. distinguenda has previously been assigned, in our opinion, to celated specimens of $U$. margaritifera ("agrading" morph, sensu Peypouquet et al. 1988), and it is not even a valid subspecies. Furthermore, we have considered U. margaritifera alba as a "fully non-celated" ("degrading" sensu Peypouquet et 
AIELLO G. et al., Shell variability of Urocythereis in the La Strea Bay (Italy)

al. 1988) morph of U. margaritifera. In the La Strea Bay this form is absent, probably due to the persisting supersaturation of calcium carbonate, as demonstrated by the high percentage of miliolids in taphocoenoses of the bay, ranging from $12.16 \%$ to $35.08 \%$ (Aiello et al. 2006). Actually, miliolids are benthic foraminifera preferring waters rich in calcium carbonate (e.g., Jorissen 1988) and very rare in low pH environments (e.g., Aiello et al. 2012 and references therein). In such a calcium super-saturated environment, all the adult specimens, and rare penultimate instars, show at least a moderate celation. Since the La Strea Bay is populated by a subtropical biocoenosis, our observations are in agreement with the statement of Peypouquet et al. (1988), who pointed out the relationship between aggradation and high water temperature.

In U. ilariae sp. nov., the less developed celation highlights different behaviour in Urocythereis species. Consequently, we suggest that three main factors influence the tegmen development: a genetically determined (specific) ability to express celation, the saturation in $\mathrm{CaCO}_{3}$ of the bottom waters and the age of the organism (adult or penultimate instar). Urocythereis margaritifera, $U$. m. alba and $U$. distinguenda are morphotypes derived by environmentally cued variability.

The definition of the variability in a single population may provide, in our opinion, a step toward a broader understanding of the variability within Urocythereis through time and space.

Morphological variations of shallow marine ostracod species living in different areas (e.g., Ishizaki 1975; Hartmann 1982) may be interpreted as the beginning of an allopatric speciation, and future investigations of the U. margaritifera / U. britannica group could discriminate these species or, conversely, demonstrate that they are subspecies or morphotypes. A more complex problem is the definition of the relationship of the Miocene Atlantic Urocythereis pertaining to the U. favosa group (e.g., U. favosa in Nascimento 1988) that possibly recolonized the Mediterranean at the end of the Salinity Crisis with the PlioceneRecent forms. An estimation of the total number of Urocythereis species in the Mediterranean Neogene and their phylogenetic relationships represent open questions.

\section{Acknowledgment}

The authors thank Alexander Liebau for some useful suggestions in the very beginning of this investigation, Dave Horne and an anonymous reviewer for their helpful comments and Roberto de' Gennaro (Cisag, Università di Napoli Federico II) who took the SEM micrographs.

\section{References}

Aiello G., Barattolo F., Barra D., Fiorito G., Mazzarella A., Raia P. \& Viola R. 2007. Fractal analysis of ostracod shell variability: A comparison with geometric and classic morphometrics. Acta Paleontologica Polonica 52: 563-573.

Aiello G., Barra D., Coppa M.G., Valente A. \& Zeni F. 2006. Recent infralittoral Foraminiferida and Ostracoda from the Porto Cesareo Lagoon (Ionian Sea, Mediterranean). Bollettino della Società Paleontologica Italiana 45: 1-14.

Aiello G., Barra D., De Pippo T. \& Donadio C. 2012. Pleistocene Foraminiferida and Ostracoda from the Island of Procida (Bay of Naples, Italy). Bollettino della Società Paleontologica Italiana 51: 49-62.

Aiello G., Barra D. \& Parisi R. 2013. Variability in ornament and shape of the genus Urocythereis from a Southern Italy bay (Ionian Sea). Il Naturalista Siciliano, IV serie 37: 21-24.

Aiello G., Coimbra J.C. \& Barra D. 2004. Ruggiericythere, a new shallow marine ostracod genus from Brazil. Bollettino della Società Paleontologica Italiana 43: 71-90. 
Aiello G. \& Szczechura J. 2001. An ostracod marker for the Upper Badenian (Miocene) of the Central Paratethys. Bollettino della Società Paleontologica Italiana 40: 75-79.

Al-Furaih A.A.F. 1977. Cretaceous and Palaeocene species of the ostracod Hornibrookella from Saudi Arabia. Palaeontology 20: 483-502.

Aranki J.F. 1987. Marine Lower Pliocene Ostracoda of southern Spain with notes on the Recent fauna. Bulletin of the Geological Institutions of the University of Uppsala, New Series 13: 1-94.

Arbulla D., Pugliese N. \& Russo A. 2001. Ostracodi del Golfo Saline (Sardegna nord-orientale). Studi Trentini di Scienze Naturali - Acta Geologica 77: 25-35.

Athersuch J. 1977. The genus Urocythereis (Crustacea: Ostracoda) in Europe, with particular reference to Recent Mediterranean species. Bulletin of the British Museum of Natural History (Zoology) 32: 247283.

Athersuch J. 1979. The ecology and distribution of the littoral ostracods of Cyprus. Journal of Natural History 13: 135-160. http://dx.doi.org/10.1080/00222937900770111a

Athersuch J. 1982. Cythereis distinguenda Neviani, 1928, Cythere crispata Brady, 1868 and Cythere pavonia Brady, 1866 (Crustacea, Ostracoda): proposed conservation of type material and validation of lectotypes and a holotype. Bulletin of Zoological Nomenclature 39: 226-227.

Athersuch J., Horne D.J. \&. Whittaker J.E. 1989. Marine and Brackish Water Ostracods. In: Kermack D.M. \& Barnes R.S.K. (eds) Synopses of the British Fauna (new series) 43, The Linnean Society of London, The Estuarine and Brackish-water Sciences Association, Leiden.

Baltanás A., Brauneis W., Danielopol D.L. \& Linhart J. 2003. Morphometric methods for applied ostracodology: tools for outline analysis of nonmarine ostracodes. In: Park L.E. \& Smith A.J. (eds) Bridging the Gap: Trends in the Ostracode Biological and Geological Sciences: 101-118. The Paleontological Society Papers 9, Tuscaloosa.

Baltanás A. \& Danielopol D.L. 2011. Geometric Morphometrics and its use in ostracod research: a short guide. Joannea Geologie und Paläontologie 11: 235-272.

Barbeito-Gonzalez P.J. 1971. Die Ostracoden des Küstenbereiches von Naxos (Griechenland) und ihre Lebensbereiche. Mitteilungen aus dem hamburgischen zoologischen Museum und Institut 67: 255-326.

Barra D. 1997. The shallow water marine ostracods of Tripoli (Libya) and their geographical distribution in the Mediterranean. Revista Española de Micropaleontología 29: 71-106.

Bassiouni M.A. 1965. Ostracoden aus dem "Pliozän" von Kom el Shelul, Pyramiden-Plateau, Gizeh (Ägypten). Geologisches Jahrbuch 82: 631-653.

Belmonte G. \& Rubino G. 1988. Chimica e fisica delle acque. In: Cinelli F., Cognetti G., Grasso M., Mongelli S., Orlando E. \& Pagliai A.M. (eds) Studio Ecologico dell'Area Marina di Porto Cesareo: 3147. Congedo Editore, Galatina.

Benson R.H. 1971. A new Cenozoic deep-sea genus, Abyssocythere (Crustacea: Ostracoda: Trachyleberididae), with descriptions of five new species. Smithsonian Contributions to Paleobiology 7: $1-25$.

Benson R.H. 1972. The Bradleya problem with descriptions of two new psychrospheric ostracode genera, Agrenocythere and Poseidonamicus (Ostracoda: Crustacea). Smithsonian Contributions to Paleobiology 12: 1-138.

Bonaduce G., Ciampo G. \& Masoli M. 1976. Distribution of Ostracoda in the Adriatic Sea. Pubblicazioni della Stazione Zoologica di Napoli 40: 1-304. 
AIELLO G. et al., Shell variability of Urocythereis in the La Strea Bay (Italy)

Brady G.S. 1866. On new or imperfectly known species of marine Ostracoda. Transactions of the Zoological Society of London 5: 359-393. Available from http://biodiversitylibrary.org/page/30838399 [accessed 9 Mar. 2016]

Breman E. 1976. The Distribution of Ostracodes in the Bottom Sediments of the Adriatic Sea. Academisch Proefschrift, Vrije Universiteit te Amsterdam, Holland.

Clark W.C. 1976. The environment and the genotype in polymorphism. Zoological Journal of the Linnean Society 58: 255-262. http://dx.doi.org/10.1111/j.1096-3642.1976.tb00831.x

Clarke K.R. \& Gorley R.N. 2006. Primer v6. Computer programme. Plymouth (PRIMER-E Ltd.)

Danielopol D.L., Buttinger R., Pipík R., Gross M., Olteanu R. \& Knoblechner J. 2008. Miocene "Hungarocypris" species of Lake Pannon (Central and South-Eastern Europe) transferred to Herpetocyprella Daday, 1909 (Ostracoda, Cyprididae). Senckenbergiana Lethaea 88: 147-160.

Doruk N. 1974. On Urocythereis favosa (Roemer). Stereo-Atlas of Ostracod Shells 2: 33-44.

Ford E.B. 1940. Polymorphism and taxonomy. In: Huxley J. (ed.) The New Systematics: 493-513. Clarendon Press, Oxford.

Gherardi M., Giangrande A. \& Corriero G. 2001. Epibiontic and endobiontic polychaetes of Geodia cydonium (Porifera, Demospongiae) from the Mediterranean Sea. Hydrobiologia 443: 87-101. http:// dx.doi.org/10.1023/A:1017500321330

Gross M., Minati K., Danielopol D.L. \& Piller W.E. 2008. Environmental changes and diversification of Cyprideis in the Late Miocene of the Styrian Basin (Lake Pannon, Austria). Senckenbergiana Lethaea 88: $161-181$.

Guillaume M.C., Peypouquet J.P. \& Tetart J. 1985. Quaternaire et Actuel. In: Oertli H.J. (ed.) Atlas des Ostracodes de France: 337-377. Centres de Recherches Exploration-Production Elf-Aquitaine, Mémoires 9, Pau.

Hagerman L. 1969. Environmental factors affecting Hirscmannia viridis (O.F. Müller) (Ostracoda) in shallow brackish water. Ophelia 7: 79-99.

Hartmann G. 1982. Variation in surface ornamentation of the valves of three ostracod species from Australia. In: Bate R.H., Robinson E. \& Sheppard L.M. (eds) Fossil and Recent Ostracods: 365-380. The British Micropaleontological Society, Ellis Horwood Limited Publishers, Chichester.

Hartmann G. \& Puri H.S. 1974. Summary of neontological and paleontological classification of Ostracoda. Mitteilungen aus dem hamburgischen zoologischen Museum und Institut 70: 7-73.

Horne D.J. 1983. Life-cycles of podocopid Ostracoda - a review (with particular reference to marine and brackish-water species). In: Maddocks R.F. (ed.) Application of Ostracoda: 581-590. Dept of Geosciences, University of Houston.

Hunt G. 2007a. Evolutionary divergence in directions of high phenotypic variance in the ostracode genus Poseidonamicus. Evolution 61: 1560-1576. http://dx.doi.org/10.1111/j.1558-5646.2007.00129.x

Hunt G. 2007b. Morphology, ontogeny, and phylogenetics of the genus Poseidonamicus (Ostracoda: Thaerocytherinae). Journal of Paleontology 81: 607-631. http://dx.doi.org/10.1666/pleo00223360(2007)081[0607:MOAPOT]2.0.CO;2

Hunt G. \& Yasuhara M. 2010. A fossil record of developmental events: variation and evolution in epidermal cell divisions in ostracodes. Evolution and Development 12: 635-646. http://dx.doi. org/10.1111/j.1525-142X.2010.00448.X 
Iepure S., Namiotko T. \& Danielopol D.L. 2007. Evolutionary and taxonomic aspects within the species group Pseudocandona eremita (Vejdovský) (Ostracoda, Candonidae). Hydrobiologia 585: 159-180. http://dx.doi.org/10.1007/s10750-007-0636-3

Irizuki T. 1993. Morphology and taxonomy of some Japanese hemicytherine Ostracoda with particular reference to ontogenetic changes of marginal pores. Transactions and Proceedings of the Palaeontological Society of Japan, New Series 170: 186-211.

Ishizaki K. 1975. Morphological variation in Leguminocythereis ? hodgii (Brady), Ostracoda (Crustacea) from Japan. In: Swain F.M. (ed.) Biology and paleobiology of Ostracoda. Bulletins of American Paleontology 65: 245-262.

Jones P.J. 1988. Carapace sculpture in Amphissites (Kirkbyacea: Ostracoda). In: Hanai T., Ikeya N. \& Ishizaki K. (eds) Evolutionary Biology of Ostracoda, its Fundamentals and Applications: 341-351. Developments in Palaeontology and Stratigraphy 11, Kodansha and Elsevier, Tokyo.

Jorissen F.J. 1988. Benthic foraminifera from the Adriatic Sea; Principles of phenotypic variation. Utrecht Micropaleontological Bulletins 37: 1-176.

Keen M.C. 1982. Intraspecific variation in Tertiary ostracods. In: Bate R.H., Robinson E. \& Sheppard L.M. (eds) Fossil and Recent Ostracods: 381-405. The British Micropaleontological Society, Ellis Horwood Limited Publishers, Chichester.

Kielbowicz A.A. 1988. Upper Oligocene-Lower Miocene Ostracods from the YPF. SCA. ECa. X-1 (E1 Campamento) Borehole, Austral Basin, Argentina. In: Hanai T., Ikeya N. \& Ishizaki K. (eds) Evolutionary Biology of Ostracoda, its Fundamentals and Applications: 1125-1145. Developments in Palaeontology and Stratigraphy 11. Kodansha and Elsevier, Tokyo.

Kubanç C. 1995. Ege Denizi Ostrakod (Crustacea) Faunası. Ph.D. Thesis, Istanbul University, Turkey.

Lachenal A.M. 1989. Écologie des ostracodes du domaine méditerranéen: application au Golfe de Gabès (Tunisie orientale). Les variations du niveau marin depuis 30000 ans. Documents des Laboratoires de Géologie de Lyon 108: 1-239.

Liebau A. 1969. Homologisierende Korrelationen von Trachyleberididen-Ornamenten (Ostracoda, Cytheracea). Neues Jahrbuch für Geologie und Paläontologie 7: 390-402.

Liebau A. 1971. Homologe Skulpturmuster bei Trachyleberididen und verwandten Ostrakoden. PhD Thesis, University School of Engineering, Berlin. [English translation, 1977, for the Smithsonian Institution, by Nolit Publishing House, Belgrade.]

Liebau A. 1991. Skulptur-Evolution bei Ostrakoden am Beispiel europäischer "Quadracytheren". Geologie und Paläontologie in Westfalen 13: 1-395.

Liebau A. 2005. A revised classification of the higher taxa of the Ostracoda (Crustacea). Hydrobiologia 538: 115-137.

Ligios S. \& Gliozzi E. 2012. The genus Cyprideis Jones, 1857 (Crustacea, Ostracoda) in the Neogene of Italy: A geometric morphometric approach. Revue de Micropaléontologie 55: 171-207. http://dx.doi. org/10.1016/j.revmic.2012.09.002

Linhart J., Brauneis W., Neubauer W. \& Danielopol D.L. 2006. Morphomatica, computer program version 1.6. Available from http://palstrat.uni-graz.at/methods\%20in $\% 20$ ostracodology/methods $\% 20$ in\%20ostracodology.htm [accessed 9 Mar. 2016]

Martens K., Rossetti G. \& Geiger W. 1998. Intraspecific morphological variability of limbs. In: Martens K. (ed) Sex and Parthenogenesis. Evolutionary Ecology of Reproductive Modes in Non-Marine Ostracods: 143-155. Backhuys Publishers, Leiden. 
AIELLO G. et al., Shell variability of Urocythereis in the La Strea Bay (Italy)

Mazzini I., Gliozzi E., Rossetti G. \& Pieri V. 2014. The Ilyocypris puzzle: A multidisciplinary approach to the study of phenotypic variability. International Review of Hydrobiology 99: 395-408. http://dx.doi. org/10.1002/iroh.201301729

M'Coy F. 1844. A Synopsis of the Characters of the Carboniferous Limestone Fossils of Ireland. University Press, Dublin.

Mercurio M., Corriero G., Liaci L.S. \& Gaino E. 2000. Silica content and spicule size variations in Pellina semitubulosa (Porifera: Demospongiae). Marine Biology 137: 87-92. http://dx.doi.org/10.1007/ $\underline{\mathrm{s} 002270000336}$

Mostafawi N. 1989. Limnische und marine Ostracoden aus dem Neogen von Insel Rhodos, Griechenland. Courier Forschungsinstitut Senckerberg 113: 117-157.

Mostafawi N. 1994. Ostracoden dem Ober-Pliozän und dem Ober-Pleistozän des N-Peloponnes, Griechenland. Neues Jahrbuch für Geologie und Paläontologie - Abhandlungen 194: 95-114.

Mostafawi N. \& Matzke-Karasz R. 2006. Pliocene Ostracoda of Cephalonia, Greece. The unrevised species of Uliczny (1969). Revista Española de Micropaleontología 38: 11-48.

Müller G.W. 1894. Die Ostracoden des Golfes von Neapel und der angrenzenden Meeres-Abschnitte. Fauna und Flora des Golfes von Neapel und der angrenzenden Meeres-Abschnitte 21: 1-404.

Müller O.F. 1785. Entomostraca seu Insecta Testacea, quae in Aquis Daniae et Norvegiae Reperit, Descripsit et Iconibus Illustravit. Leipzig and Copenhagen.

Nascimento A. 1988. Ostracodos do Miocénico da Bacia do Tejo: Sistematica, Biostratigrafia, Paleoecologia, Paleogeografia e Relaçoes Mediterraneo-Atlantico. PhD Thesis, Universidade Nova de Lisboa, Portugal.

Neil J.W. 2000. Factors influencing intraspecific variation and polymorphism in marine podocopid Ostracoda, with particular reference to Tertiary species from southeastern Australia. Hydrobiologia 419: 161-180. http://dx.doi.org/10.1023/A:1003983918339

Neviani A. 1928. Ostracodi fossili d'Italia. 1: Vallebiaja (Calabriano). Memorie della Pontificia Accademia dei Nuovi Lincei 81: 123-132.

Okada Y. 1981. Development of cell arrangement in ostracod carapaces. Paleobiology 7: 276-280.

Okada Y. 1982a. Structure and cuticle formation of the reticulated carapace of the ostracode Bicornucythere bisanensis. Lethaia 15: 85-101. http://dx.doi.org/10.1111/j.1502-3931.1982.tb01978.x

Okada Y. 1982b. Ultrastructure and pattern of the carapace of Bicornucythere bisanensis (Ostracoda, Crustacea). In: Hanai T. (ed.) Studies on Japanese Ostracoda: 229-267. University of Tokyo Press, Tokyo.

Parenzan P. 1976. Un habitat marino di tipo subtropicale, a Porto Cesareo. Atti del VI Simposio Nazionale per la Conservazione della Natura: 151-157. Bari.

Parenzan P. 1983. Puglia Marittima. Aspetti Geologici e Biologia Marina (1-2). Congedo Editore, Galatina.

Parenzan P. 1984. L'insenatura della Strea di Porto Cesareo. Thalassia Salentina 14: 27-38.

Perçin-Paçal F. \& Balkis H. 2012. Seasonal distribution of Ostracoda in Bandirma Bay and Erdek Bay, Sea of Marmara, Turkey. Crustaceana 85: 847-875. http://dx.doi.org/10.1163/156854012X650791

Peypouquet J.P., Carbonel P., Ducasse O., Tölderer-Farmer M. \& Lété C. 1988. Environmentally cued polymorphism of ostracods. A theoretical and practical approach. A contribution to geology and to the understanding of ostracod evolution. In: Hanai T., Ikeya N. \& Ishizaki K. (eds) Evolutionary Biology 
of Ostracoda, its Fundamentals and Applications: 1003-1019. Developments in Palaeontology and Stratigraphy 11, Kodansha and Elsevier, Tokyo.

Peypouquet J.P., Ducasse O., Gayet J. \& Pratviel L. 1980. “Agradation et Dégradation”, des Tests d'Ostracodes. Intérêt pour la Connaissance de l'Évolution Paléohydrologique des Domaines Marginolittoraux Carbonatés: 357-369. Actes Réunion "Cristallisation, Déformation, Dissolution des Carbonates", Bordeaux.

Peypouquet J.P., Ducasse O. \& Rousselle L. 1981. Morphogenesis and environment. Theoretical and practical aspects from Hammatocythere: Paleogene Ostracoda of the Aquitaine Basin. In: Martinell J. (ed.) International Symposium on Concepts and Methods in Paleontology: 173-187. Departamento de Paleontologia, Universitat de Barcelona, Barcelona.

Pokorny V. 1969a. The genus Radimella Pokorny, 1969 (Ostracoda, Crustacea) in the Galapagos Islands. Acta Universitatis Carolinae, Geologica 4: 293-334.

Pokorny V. 1969b. Radimella gen. n. a new genus of the Hemicytherinae (Ostracoda, Crust.). Acta Universitatis Carolinae, Geologica 4: 359-373.

Puri H.S. 1974. Normal pores and the phylogeny of Ostracoda. Geoscience and Man 6: 137-151.

Rossetti G. \& Martens K. 1996. Redescription and morphological variability of Darwinula stevensoni (Brady \& Robertson, 1870) (Crustacea, Ostracoda). Bulletin de l'Institut Royal des Sciences Naturelles de Belgique, Biologie 66: 73-92.

Ruggieri G. 1950. Gli ostracodi delle sabbie grigie quaternarie (Milazziano) di Imola. Parte I. Giornale di Geologia 21: 1-57.

Ruggieri G. 1953. Età e faune di un terrazzo marino sulle coste ioniche della Calabria. Giornale di Geologia 23: 20-168.

Ruggieri G. \& Russo A. 1980. Due nuovi generi di ostracodi marini del Miocene superiore italiano. Bollettino della Società Paleontologica Italiana 19: 25-35.

Ruiz F., Abad M., Carbonel P. \& Muñoz J.M. 2006. Polymorphism in recent ostracods of southwestern Spain: an environmental approach. Geobios 39: 311-317. http://dx.doi.org/10.1016/j. geobios.2004.09.003

Şafak Ü., Avşar N. \& Meriç E. 1999. Ostracoda and benthic foraminifera of Tertiary sequence of western part of Istanbul. 4th European Ostracodologists Meeting. Yerbilimleri, Special Issue 35: 173-201.

Schornikov E.I. 1969. Podklass Ostracoda, ili rakushkovye rachki, Ostracoda Latreille, 1816. Opredelitel fauny Chernogo i Azovogo Morey 2: 163-259.

Scott H.W. 1961. Shell morphology of Ostracoda. In: Moore R.C. \& Pitrat C.W. (eds) Treatise on Invertebrate Paleontology, Q, Arthropoda 3: 21-37. The University of Kansas, Lawrence, Kansas.

Sissingh W. 1972. Late Cenozoic Ostracoda of the South Aegean Island Arc. Utrecht Micropaleontological Bulletins 7: 1-187.

Stancheva M. 1989. Holocene ostracod zones of the Western Black Sea shelf. Geologica Balcanica 19: 91-95.

Sylvester-Bradley P.C. 1976. Speciation patterns in the Ostracoda. In: Hartmann G. (ed.) Abhandlungen und Verhandlungen der Naturwissenschaftlichen Vereins in Hamburg (N/F) 18-19 (Suppl.): 29-37.

Sylvester-Bradley P.C. \& Benson R.H. 1971. Terminology for surface features in ornate ostracodes. Lethaia 4: 249-286. http://dx.doi.org/10.1111/j.1502-3931.1971.tb01924.x 
AIELLO G. et al., Shell variability of Urocythereis in the La Strea Bay (Italy)

Tanaka G., Hatanaka K. \& Ikeya N. 2011. Systematics and stability of carapace ornamentation of the genus Ambolus (Crustacea, Ostracoda) from the Southern Hemisphere. Paleontological Research 15: $125-145$.

Terquem M.O. 1878. Les foraminifères et les entomostracés-ostracodes du Pliocène supérieur de l'île de Rhodes. Mémoires de la Société Géologique de France 3: 1-135.

Triantaphyllou M.V., Tsourou T., Koukousioura O. \& Dermitzakis M.C. 2005. Foraminiferal and ostracod ecological patterns in coastal environments of SE Andros Island (Middle Aegean Sea, Greece). Revue de Micropaléontologie 48 (4): 279-302. http://dx.doi.org/10.1016/j.revmic.2005.09.003

Tsapralis V. 1981. Contribution to the Study of the Pleistocene of Zakynthos Island, W. Greece (OstracodaPalaeoenvironment). Ph.D. Thesis, University of Patras, Greece.

Tunoğlu C. 1999. Recent Ostracoda association in the Sea of Marmara, NW Turkey. Bulletin of Earth Sciences Application and Research Centre of Hacettepe University 21: 63-89.

Uffenorde H. 1972. Ökologie und jahreszeitliche Verteilung rezenter bentonischer Ostracoden des Limski Kanal bei Rovinj (nördliche Adria). Göttinger Arbeiten zur Geologie und Paläontologie 13: $1-121$.

Uliczny F. 1969. Hemicytheridae und Trachyleberididae (Ostracoda) aus dem Pliozän der Insel Kephallinia (Westgriechenland). Doctor Thesis, Fakultät der Ludwig-Maximilians Universität zu München, Germany.

Van Morkhoven F.P.C.M. 1962. Post-Palaeozoic Ostracoda 1. Elsevier Publishing Company, Netherlands, Amsterdam.

West-Eberhard M.J. 1989. Phenotypic plasticity and the origins of diversity. Annual Review of Ecology and Systematics 20: 249-278. http://dx.doi.org/10.1146/annurev.es.20.110189.001341

Wouters K. 1973. Quelques ostracodes de Tyrrhénien de Monastir (Tunisie). Livre Jubilaire M. Solignac. Annales des Mines et de la Géologie 26: 379-399.

Yin Y., Geiger W. \& Martens K. 1999. Effects of genotype and environment on phenotypic variability in Limnocythere inopinata (Crustacea: Ostracoda). Hydrobiologia 400: 85-114. http://dx.doi. org/10.1023/A:1003759125903

Manuscript received: 13 October 2015

Manuscript accepted: 14 December 2015

Published on: 3 May 2016

Topic editor: Rudy Jocqué

Desk editor: Kristiaan Hoedemakers

Printed versions of all papers are also deposited in the libraries of the institutes that are members of the EJT consortium: Muséum national d'Histoire naturelle, Paris, France; Botanic Garden Meise, Belgium; Royal Museum for Central Africa, Tervuren, Belgium; Natural History Museum, London, United Kingdom; Royal Belgian Institute of Natural Sciences, Brussels, Belgium; Natural History Museum of Denmark, Copenhagen, Denmark. 